\title{
Plugged into the Ku-DNA hub: The NHEJ network
}

\author{
Philippe Frit a, b, Virginie Ropars ${ }^{c}$, Mauro Modesti ${ }^{\text {d, e }}$, Jean Baptiste Charbonnier ${ }^{\text {c, *, }}$ \\ Patrick Calsou ${ }^{\text {a, b, *** }}$ \\ a Institut de Pharmacologie et Biologie Structurale, IPBS, Université de Toulouse, CNRS, UPS, Toulouse, France \\ ${ }^{\mathrm{b}}$ Equipe Labellisée Ligue Contre le Cancer, Toulouse, France \\ ${ }^{\mathrm{c}}$ Institute for Integrative Biology of the Cell (I2BC), Institute Joliot, CEA, CNRS, Univ. Paris-Sud, Université Paris-Saclay, 91198, Gif-sur-Yvette Cedex, France \\ d Cancer Research Center of Marseille, CNRS UMR7258, Inserm U1068, Institut Paoli-Calmettes, Aix-Marseille Université UM105, Marseille, France \\ ${ }^{\mathrm{e}}$ Equipe Labellisée Ligue Contre le Cancer, Marseille, France
}

\section{A R T I C L E I N F O}

\section{Article history:}

Received 31 October 2018

Received in revised form

26 February 2019

Accepted 1 March 2019

Available online $\mathrm{xxx}$

\section{Keywords:}

DNA damage

NHEJ

Double-strand breaks

$\mathrm{Ku}$

Protein interactions network

DNA repair machineries

Conserved binding motifs

\begin{abstract}
A B S T R A C T
In vertebrates, double-strand breaks in DNA are primarily repaired by Non-Homologous End-Joining (NHEJ). The ring-shaped Ku heterodimer rapidly senses and threads onto broken DNA ends forming a recruiting hub. Through protein-protein contacts eventually reinforced by protein-DNA interactions, the Ku-DNA hub attracts a series of specialized proteins with scaffolding and/or enzymatic properties. To shed light on these dynamic interplays, we review here current knowledge on proteins directly interacting with $\mathrm{Ku}$ and on the contact points involved, with a particular accent on the different classes of Kubinding motifs identified in several Ku partners. An integrated structural model of the core NHEJ network at the synapsis step is proposed.
\end{abstract}

๑ 2019 Elsevier Ltd. All rights reserved.

\section{Contents}

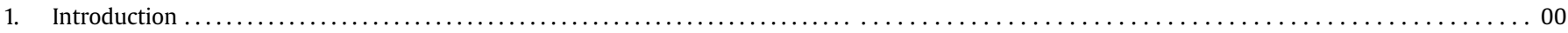

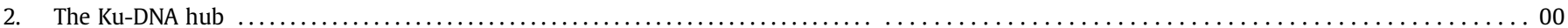

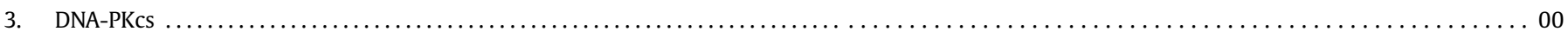

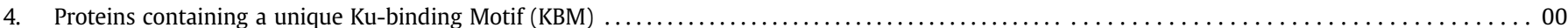

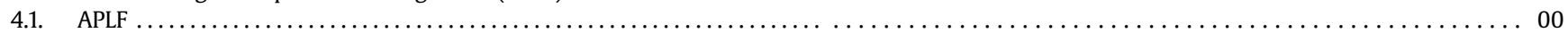

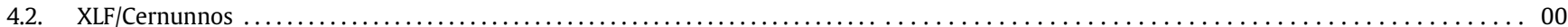

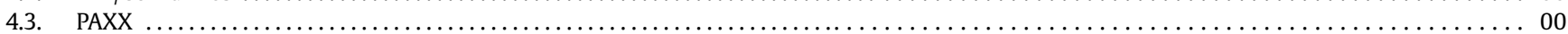

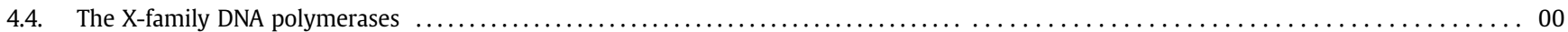

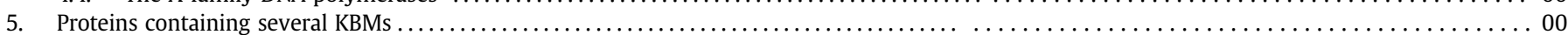

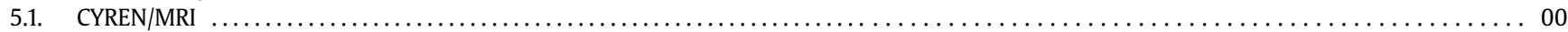

Abbreviations: APLF, APTX and PNKP-like factor; BRCT, BRCA1 C-Terminus domain; Cryo-EM, cryo-electron microscopy; CTD, C-terminal domain; CYREN, cell-cycle

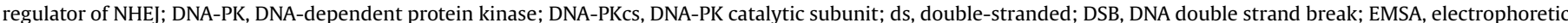

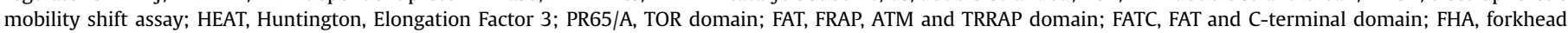

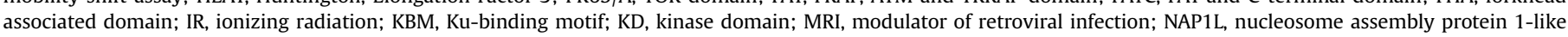

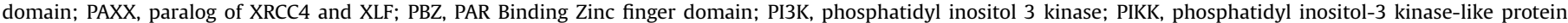

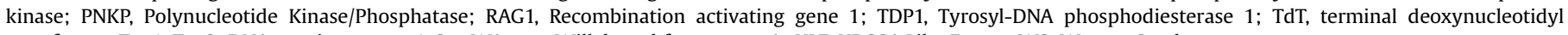
transferase; Top1, Top2, DNA topoisomerase 1, 2; vWA, von Willebrand factor type A; XLF, XRCC4-Like Factor; WS, Werner Syndrome.

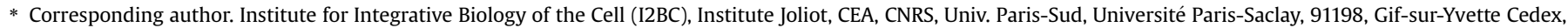
France.

** Corresponding author. Institut de Pharmacologie et Biologie Structurale, IPBS, Université de Toulouse, CNRS, UPS, Toulouse, France.

E-mail addresses: jb.charbonnier@cea.fr (J.B. Charbonnier), calsou@ipbs.fr (P. Calsou). 


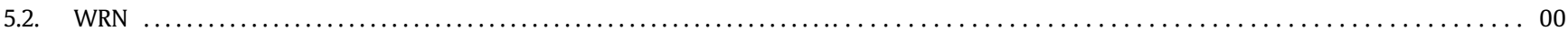

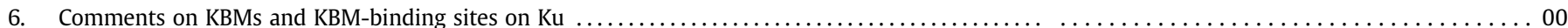

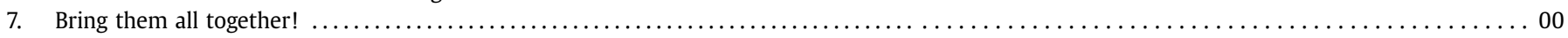

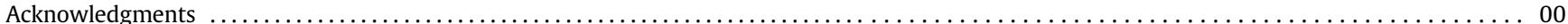

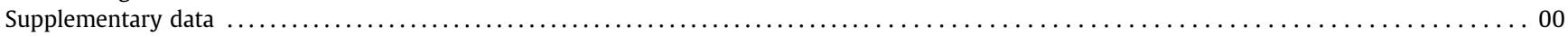

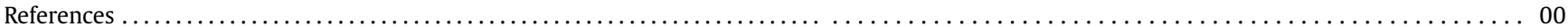

\section{Introduction}

DNA double-strand breaks (DSBs) consist in the localized breakage of both DNA strands. DSBs are genomic lesions particularly deleterious for cell homeostasis since when unrepaired or misrepaired, they can lead to cell death or to cancer-prone chromosomal aberrations (Mladenov et al., 2016). DSBs can occur from cell exposure to ionizing radiations or radiomimetic compounds, all generating breaks with two DNA ends that are generally chemically heterogeneous (Schipler and Iliakis, 2013). In vertebrates, DSBs with two ends are also intermediates in physiological processes like $\mathrm{V}(\mathrm{D}) \mathrm{J}$ recombination in lymphocyte progenitors that rearrange immunoglobulin and T-cell receptor genes (Alt et al., 2013) or DNA breakage associated with neural development and the functioning of mature neurons (Alt and Schwer, 2018). A subclass of DSBs bearing only one DNA end arises during DNA replication when the replication fork encounters single-strand breaks, or by cutting of stalled replication forks by structure-specific endonucleases (Pasero and Vindigni, 2017).

In vertebrates, the majority of DSBs with two ends is repaired by Non-Homologous End-Joining (NHEJ) (Chang et al., 2017; Lieber, 2010; Waters et al., 2014). Dysfunctions in core NHEJ factors translate into syndromes associating immunodeficiency, microcephaly and increased cell radiosensitivity (de Villartay, 2015; Woodbine et al., 2014). End-joining of DSBs is also active in some bacterial species (Bertrand et al., 2019; Glickman, 2014), in yeasts (Emerson and Bertuch, 2016) and in ciliates (Marmignon et al., 2014).

DSB recognition involves the threading onto the extremities of the DSB of the ring-shaped Ku heterodimer composed of subunits Ku70 and Ku80 (Walker et al., 2001) (Figs. 1 and 3). Because of its nuclear localization, high abundance and strong affinity for free DNA ends, within seconds, Ku likely associates with any DSB occurring in a nucleus (Mari et al., 2006). Notably, Ku also binds to single-ended DSBs occurring during DNA replication (Chanut et al., 2016) that are repaired by homologous recombination between sister chromatids (Arnaudeau et al., 2001). Since NHEJ on singleended DSBs would likely lead to undesirable translocations, cells employ a complex mechanism to remove Ku from these breaks before repair by homologous recombination (Chanut et al., 2016).

NHEJ is a versatile DNA repair pathway that can accommodate a wide variety of break ends (Betermier et al., 2014; Pannunzio et al., 2017). The current view of how the NHEJ components fit into place to ensure repair is that the Ku-DSB end complex operates as a hub that brings together a series of specialized proteins with scaffolding and/or enzymatic activities (Fell and Schild-Poulter, 2015; Grundy et al., 2014) (Fig. 1). These factors are recruited by the Ku hub via direct protein-protein contacts and eventually reinforced by protein-DNA interactions. They are involved in one or several steps of the NHEJ reaction, including DNA end protection and juxtaposition (also called synapsis), DNA end processing (most of the nonenzymatic breaks are not directly ligatable due to the lack of mandatory 3 '-OH and 5'-phosphate ends), and the final ligation. In addition to DNA ligase (DNA Ligase 4 (Lig4) within a complex with
XRCC4 and XLF/Cernunnos), enzymatic activities involved in NHEJ fall into several classes that are more or less required depending on the DNA ends chemical complexity: protein kinase (DNA-dependent protein kinase catalytic subunit - DNA-PKcs), nucleases (APLF, Artemis, Werner protein (WRN)), DNA helicase (WRN), tyrosylDNA phosphodiesterase (TDP1), polynucleotide Kinase/Phosphatase (PNKP), DNA deadenylase (Aprataxin), DNA polymerases (Pol $\mu$ and Pol $\lambda$ ) or terminal deoxynucleotidyl transferase (TdT) (Chang et al., 2017) (Fig. 1).

Although several structures of components of the NHEJ machinery, alone or in a complex, have been determined (Ochi et al., 2014; Williams et al., 2014) (Fig. 1), a complete view of the dynamic interactions between all these components is lacking. Here, we focus on the human Ku-DNA hub. We review current knowledge on its direct interactants and on the contact points involved, with a particular accent on the different classes of Ku-binding motifs (KBMs) identified so far in several Ku protein partners (Fig. 2). Comparison with equivalent features or structures in yeast will be punctually emphasized. Finally, based on the available data, an integrated structural model of the core NHEJ network at the synapsis step is proposed.

\section{The Ku-DNA hub}

The human Ku70 (70 kDa) and Ku80 (80 kDa) subunits present a common topology and domain organization with an N-terminal $\alpha / \beta$ domain that belongs to the von Willebrand (vWA) family, a central domain ( $\beta$-barrel, pillar, bridge), a C-terminal arm and a helical Cterminal domain (Figs. 1 and 3). Ku is present in yeast (Emerson and Bertuch, 2016) and in some bacteria (Glickman, 2014). The bacterial $\mathrm{Ku}$ homologues are smaller than their eukaryotic counterparts $(\sim 30-40 \mathrm{kDa})$. Their sequences align with the heterodimerization domain and they lack both the vWA domain and large C-terminal regions (see (Pitcher et al., 2007) for a review (McGovern et al., 2016)).

$\mathrm{Ku}$ binds to DNA ends, as suggested by initial biochemical studies showing that Ku prefers digested plasmid DNA on which it binds proportionally to the number of restriction cuts (de Vries et al., 1989; Mimori and Hardin, 1986). Ku binding to DNA is sequence independent, identical on blunt ends, short 5'- or 3overhangs and it requires a minimal size of $14 \mathrm{bp}$. Ku can recognize a large set of DNA ends since its binding is unaffected by the presence of hairpins (Arosio et al., 2002), chemically heterogeneous damage generated by ionizing radiations (Pang et al., 1997) or cisplatin (Turchi and Henkels, 1996). Regarding Ku affinity for DNA ends, we measured a $4.0 \pm 0.7 \mathrm{nM}$ kd between Ku and an 18 bp DNA using micro-calorimetry, with an entropy driven interaction (Nemoz et al., 2018), in agreement with previous measurements (Arosio et al., 2002, 2004; Blier et al., 1993). The same Kd was measured with a minimal Ku heterodimer lacking the Ku70 and Ku80 C-terminal regions (unpublished data). Ku interaction with DNA ends in vitro is stable since a $k_{\text {off }}$ of $1.5 \pm 0.810^{-4} \mathrm{~s}^{-1}$ was measured using Surface Plasmon Resonance with a 200 bp DNA anchored via one end on the chip, corresponding to a half-life of 


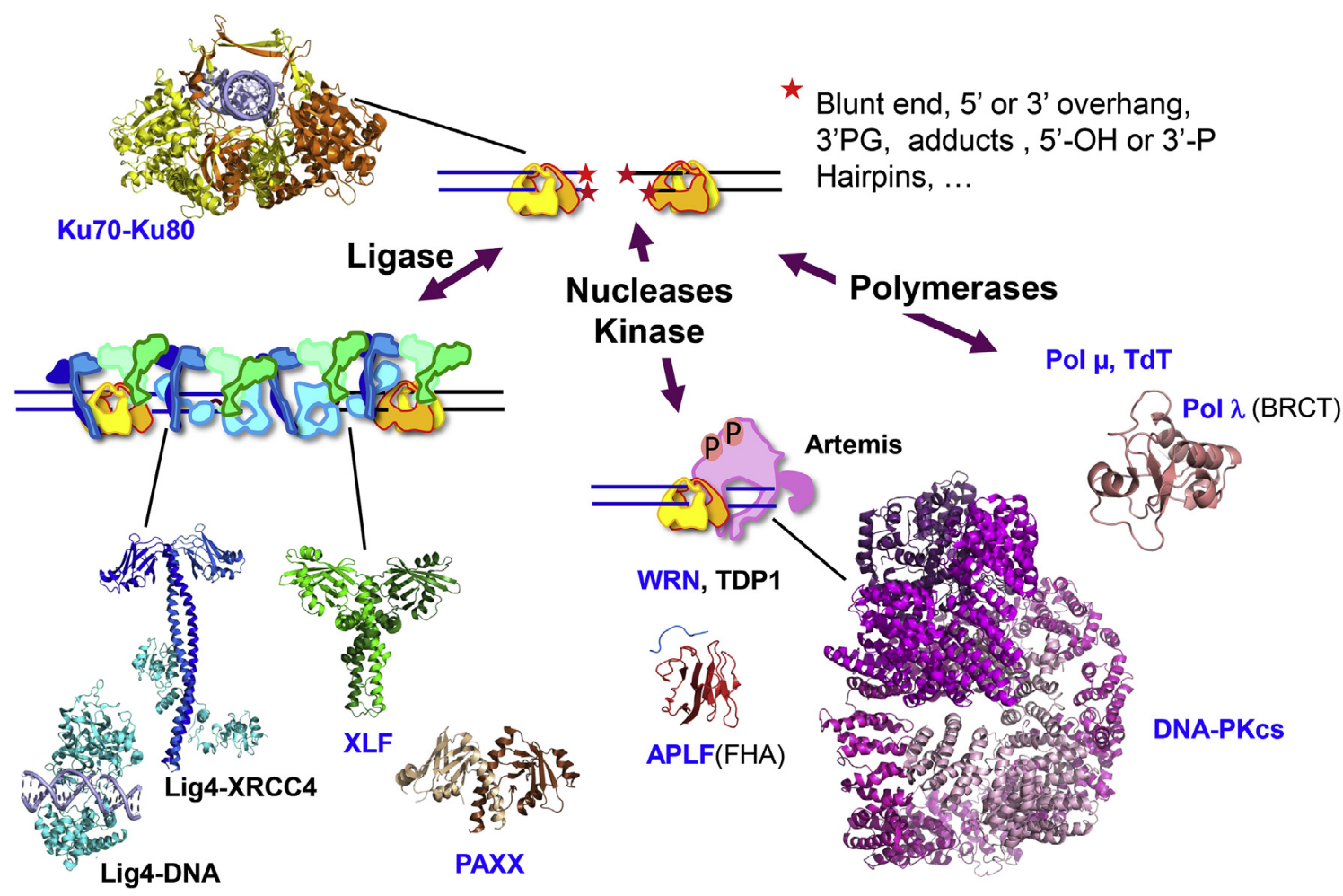

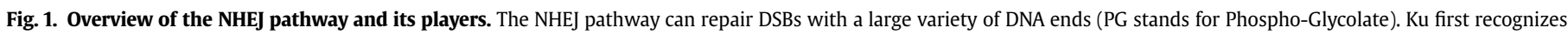

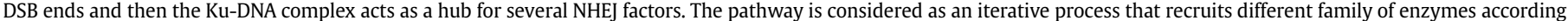

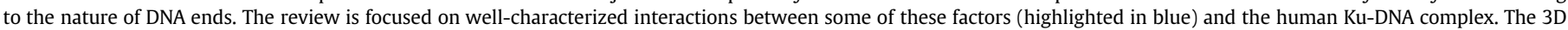

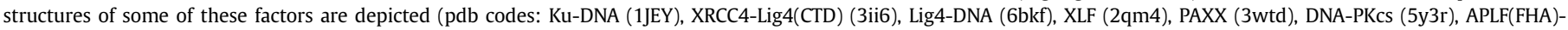
XRCC4pep (5w7x), Pol lambda(BRCT) (2jw5)).

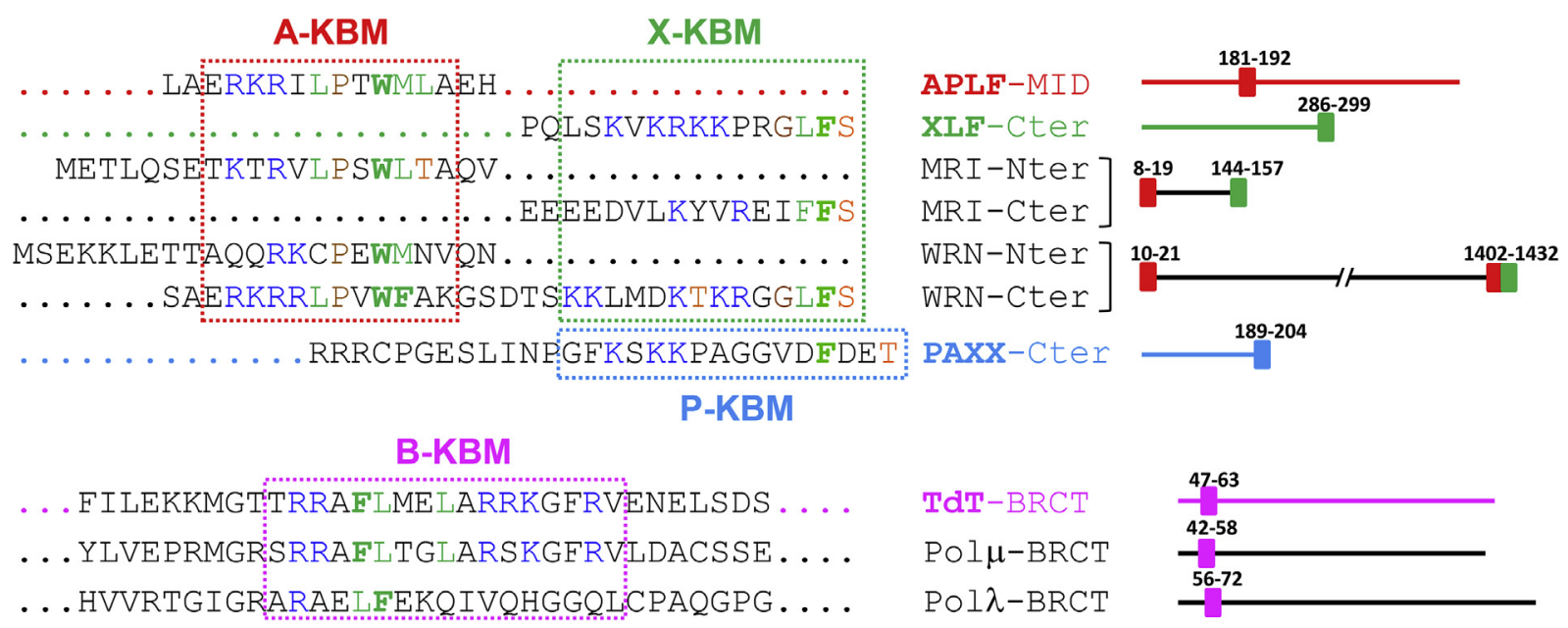

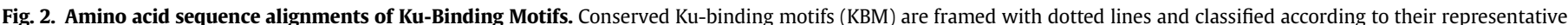

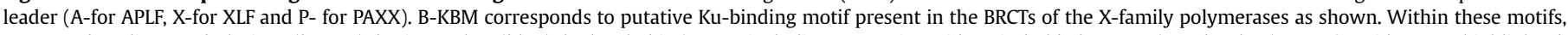

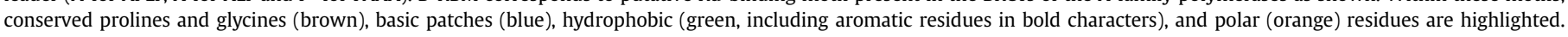
KBMs are positioned on the corresponding protein primary sequences (right).

2.7 h for Ku on DNA under these conditions (unpublished data).

The crystal structures of Ku70-Ku80 reported in 2001 by the laboratory of J. Goldberg was a milestone in the field (Walker et al., 2001). However, sixteen years passed between publication of this seminal initial structure and recent 3D structural data of Ku-DNA complexed with some Ku partners (Nemoz et al., 2018; Yin et al., 2017). The Ku construct used for the crystallization comprised the full-length Ku70 subunit and a Ku80 subunit deleted of its 19 kDa C- terminal domain. The DNA used contained a 14 bp duplex and a hairpin by annealing a $21 \mathrm{nt}$ and a $34 \mathrm{nt}$ oligonucleotide. The hairpin is favorable to position $\mathrm{Ku}$ on the 14bp duplex in all structures reported to date (Fig. 3B). The central Ku70-Ku80 domains play a key role in the interactions with DNA. The $\beta$-barrel forms the large base from which a 70 residue insertion loop defines a thin bridge that encircles the DNA (Figs. 1 and 3). The large interface between the Ku70 and Ku80 subunits, and the similarities 


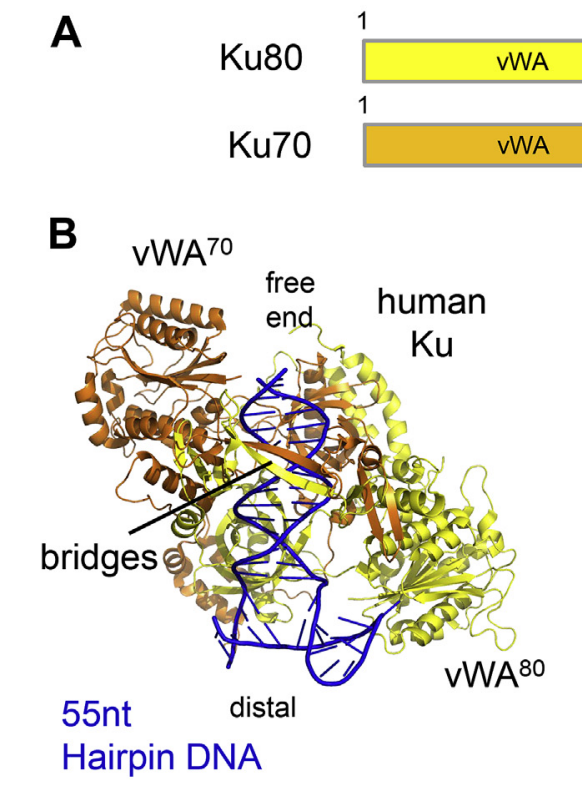

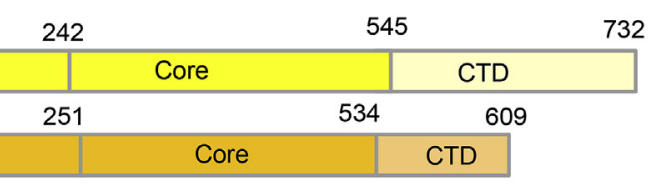

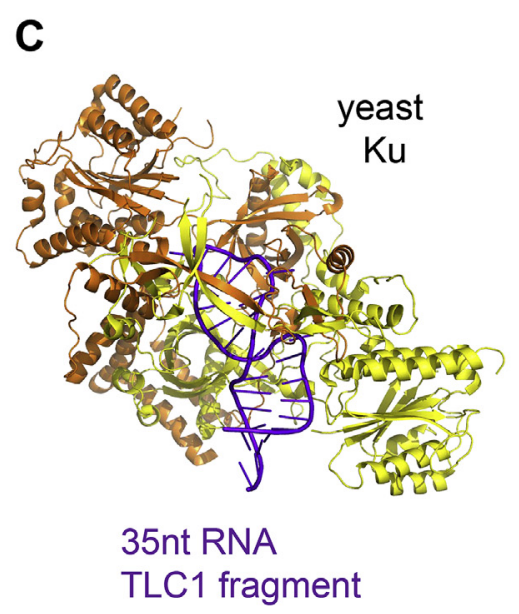

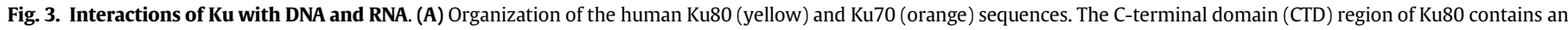

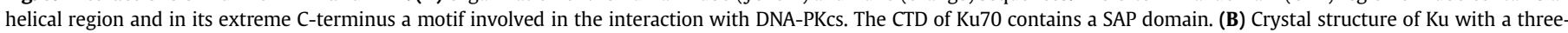

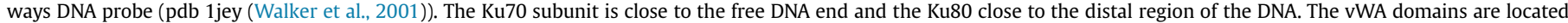

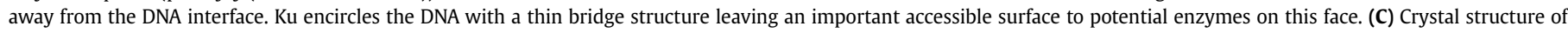

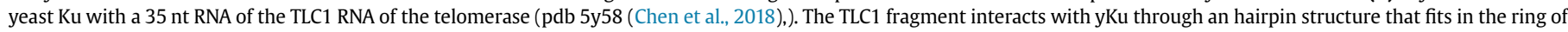
yKu.

between the crystal structures of Ku alone and the Ku-DNA complex, indicate that the Ku ring structure is pre-formed and highly stable, corroborating reports that both Ku subunits stabilize each other in cells (Gu et al., 1997). The Ku channel is bordered by positive charges and can accommodate two turns of DNA ( 20 bp) in agreement with EMSA and footprint studies. The heterodimer makes no contact with DNA bases and a few interactions with the sugar-phosphate backbone consistent with the sequence independent binding. In Saccharomyces cerevisiae, the yKu70-yKu80 heterodimer contributes to the recruitment at the telomere of the telomerase by direct interactions with its RNA component TLC1 and the Sir4 protein. A structural study recently reported that the TLC1 adopts a hairpin structure that occupies the classical aperture of the $\mathrm{yKu}$ ring, but that in this case, the RNA-yKu interaction is conformation and sequence specific (Chen et al., 2018) (Fig. 3). This suggests that in humans, some interactions reported between $\mathrm{Ku}$ and specific RNAs may adopt similar conformations (Lamaa et al., 2016).

The human Ku-DNA structure shows that one DNA face within the Ku channel is covered by a thin bridge, leaving a largely exposed DNA surface that likely facilitates the access of NHEJ enzymes to DSB ends bound by Ku. Importantly, the Ku-DNA complex is oriented, with the Ku70 subunit positioned close to the free end and the Ku80 subunit facing the distal part of the DNA, as previously proposed from photo-crosslinking analyses (Yoo et al., 1999).

The N-terminal $\alpha / \beta$ domains lie at the periphery of the Ku heterodimer (Walker et al., 2001). We and other laboratories recently characterized the role of the Ku80 vWA domain in its interaction with several NHEJ factors including XLF, APLF, WRN and CYREN (see the corresponding paragraphs below). The C-terminal domain of Ku80 (17 kDa) mediates interaction with DNA-PKcs (Gell and Jackson, 1999; Singleton et al., 1999) (see section 3.). Once bound to a DNA end, Ku can translocate to internal sites in vitro with regular patterns of $27 \mathrm{bp}$ (de Vries et al., 1989). Atomic force microscopy studies confirmed the threading capacities of Ku but also revealed additional events like DNA looping (Cary et al., 1997) or
DNA bridging (Pang et al., 1997). After re-circularization of Kubound linear DNA, Ku is highly resistant to dissociation, suggesting a "beads on a string" configuration (Paillard and Strauss, 1991). $\mathrm{Ku}$ internal sliding is an energy-free mechanism still poorly understood. In the Ku-DNA complex structure, the Ku channel fits sterically with the minor and major DNA grooves so that the channel is too tight for a linear diffusion of the DNA (Walker et al., 2001). It remains to be established whether Ku translocation requires a slight enlargement of the channel likely at the bridge level, or if Ku moves on a helical path through the DNA helix. However, Ku internal translocation has not been detected at DSBs in cells (Britton et al., 2013) where it may be limited by nucleosomes (Roberts and Ramsden, 2007) and/or controlled by interaction with its DNA-PKcs partner (see section 3.).

\section{DNA-PKCS}

DNA-dependent protein kinase catalytic subunit (DNA-PKcs) forms with the Ku heterodimer the DNA-PK holoenzyme (Gottlieb and Jackson, 1993). DNA-PKcs is the largest human kinase with a single chain of 4,128 amino acids. It belongs to the family of phosphatidyl inositol 3-kinase-like serine/threonine kinases (PIKK) that includes ATM, ATR and mTOR (Jette and Lees-Miller, 2015). Like other PIKK family members, DNA-PKcs contains a large Nterminal $\alpha$-solenoid domain, a FAT domain, and a kinase domain (KD) followed by a FATC domain (Sibanda et al., 2010). The kinase activity of DNA-PKcs is activated upon its Ku-mediated recruitment to DNA ends, as shown in vitro (Chan et al., 1996; Gottlieb and Jackson, 1993; Suwa et al., 1994) and in cells (Uematsu et al., 2007). Inhibition of this activity by small molecule inhibitors or mutation of the kinase domain compromises NHEJ (Kienker et al., 2000; Kurimasa et al., 1999; Zhao et al., 2006). The last 12 aa of Ku80 are sufficient to pull-down DNA-PKcs (Gell and Jackson, 1999), although not sufficient to activate the kinase (Bennett et al., 2012), suggesting that other regions of $\mathrm{Ku}$ are required 
(Weterings et al., 2009). Indeed, the flexible Ku80 C-terminal domain (CTD, region 545 to 732) extending from the DNA-bound core of $\mathrm{Ku}$ may be important to retain DNA-PKcs at DSBs (Hammel et al., 2010).

Structural elucidation of DNA-PKcs and DNA-PK holoenzyme has been quite elusive due to the size of the machines (RiveraCalzada et al., 2006; Sibanda et al., 2010; Spagnolo et al., 2006; Williams et al., 2008). The first studies defined the overall structures of these large macromolecules and complexes. The resolution was pushed recently to pseudo-atomic levels by crystallography and cryoEM (Sharif et al., 2017; Sibanda et al., 2017; Yin et al., 2017). In the recently reported $6.6 \AA$ resolution of DNA-PK by cryoEM, several key features of the interaction between DNA-PKcs and KuDNA were determined (Yin et al., 2017). A Y-shape DNA, with a 35 bp duplex region was used to force DNA-PK to adopt a unique position, as previously used for the crystal structure of the Ku-DNA complex (Walker et al., 2001). The authors observed a positioning of DNA-PKcs close to the DNA free end in good agreement with crosslinking experiments previously reported (Yoo et al., 1999). DNA-PKcs and Ku cover DNA over 30 bp and kink the DNA with an angle of $30^{\circ}$. They identified three major interfaces between DNAPKcs and Ku (Fig. 4). Interface-1: the $\alpha / \beta$ domain of Ku70 makes contact with the convex surface of the middle HEAT region of DNAPKcs (M-HEAT, 893-2801); interface-2: the bridge part of Ku70/ Ku80 interacts with the convex part of the $\mathrm{N}$-terminal region of the
HEAT domain (N-HEAT, 1-892); interface-3: the second $\alpha$-helix in the C-terminal region of Ku80 interacts with the concave side of the M-HEAT and is located close to the free DNA end. The interaction between DNA-PKcs, Ku and DNA induces allosteric conformational changes up to the catalytic domain of the kinase. These recent structural data explain why DNA-PKcs kinase activation requires a concomitant binding of DNA-PKcs to Ku and DNA at most DNA ends (Falck et al., 2005; Gell and Jackson, 1999; Singleton et al., 1999). However, it remains to be determined how the C-terminus of Ku80 precisely interacts with DNA-PKcs as well as how DNA-PKcs is partially activated in the absence of Ku80 CTD on some DNA ends, like those with a poly-pyrimidine single-stranded DNA extension (Pawelczak et al., 2005; Radhakrishnan and Lees-Miller, 2017; Weterings et al., 2009; Woods et al., 2015).

\section{Proteins containing a unique Ku-binding Motif (KBM)}

Biochemical and structural studies on direct interactions of $\mathrm{Ku}$ with NHEJ players have helped to define three classes of bona fide KBMs (Fig. 2). In addition, sequence and structure comparisons together with mutagenesis data suggest a fourth KBM class within the BRCT domain of three DNA polymerases from the X-family (Fig. 2). Current knowledge on proteins containing only one KBM belonging to these classes is detailed below. APLF illustrates the AKBM, XLF/Cernunnos the X-KBM, PAXX the P-KBM and X-family
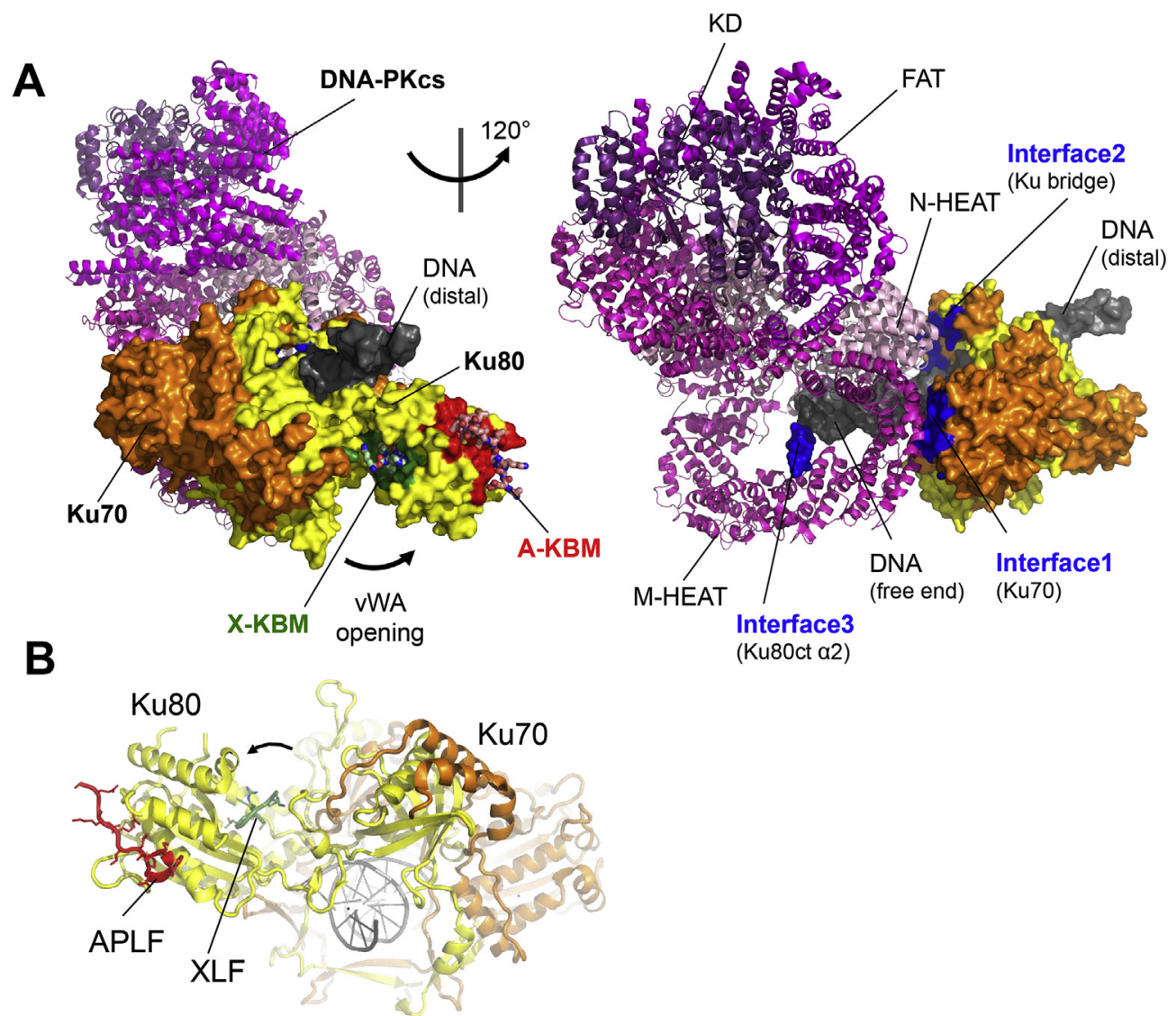

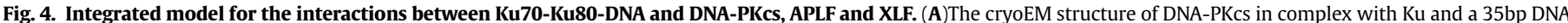

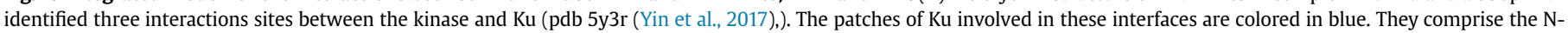

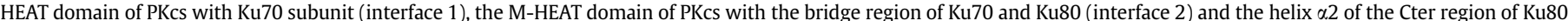

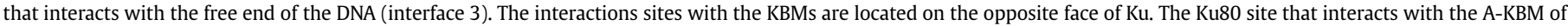

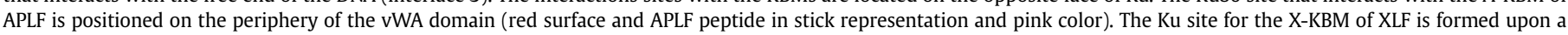

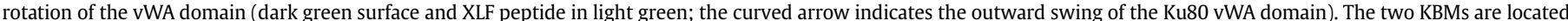

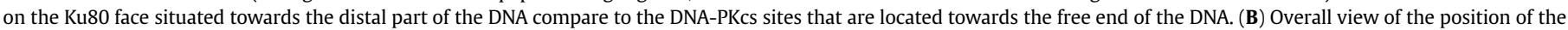
KBMs of APLF (red) and XLF (green) on human Ku heterodimer (Ku80 in yellow and Ku70 in orange). 
DNA polymerases the B-KBM class, respectively.

\subsection{APLF}

The present view of the APTX and PNKP-like factor (APLF) is that it behaves as an intrinsically disordered scaffold that binds various components of the DSB repair machinery through several domains, stabilizing the assembly of NHEJ factors around the break (Hammel et al., 2016). In addition, APLF has been reported to have nuclease activity possibly involved in limited processing of DNA ends (Kanno et al., 2007; Rulten et al., 2008).

APLF domains include at the N-terminus a forkhead associated (FHA) domain that interacts with phospho-T233 of XRCC4 (Kanno et al., 2007; Macrae et al., 2008), at the C-terminus two PARbinding zinc finger (PBZ) domains that bind poly(ADP)ribosylated proteins near DSB sites (Ahel et al., 2008; Rulten et al., 2008), and in the C-terminal tail, an acidic nucleosome assembly protein 1-like (NAP1L) domain that binds to (H3-H4) 2 and H2A-H2B histones (Corbeski et al., 2018; Mehrotra et al., 2011). In addition, the APLF central region contains an A-KBM that tightly interacts with $\mathrm{Ku}$ and is necessary for APLF recruitment to laserinduced DSBs in cells (Grundy et al., 2013; Shirodkar et al., 2013) (Fig. 2). This A-KBM interaction site has been mapped in the Ku80 vWA domain (Rulten and Grundy, 2017). We reported recently the structure of the A-KBM of APLF bound to Ku80 in a Ku-DNA complex, showing that the L68, Y74 and I112 positions in Ku80, known to disrupt the interaction with APLF when mutated (Grundy et al., 2013), indeed make tight interactions with the $\mathrm{I}_{185} \mathrm{LPTWML}_{191}$ hydrophobic part of the A-KBM motif (Nemoz et al., 2018) (Fig. 4A and $B$ ). We characterized the $\mathrm{W} 189$ residue as a key determinant for APLF specific interaction with the A-KBM binding site in Ku80 and moreover, we demonstrated that the replacement of Leu297 by a tryptophan in the XLF X-KBM (Fig. 2) was sufficient to redirect the mutated XLF peptide to the APLF binding site in Ku80 (Nemoz et al., 2018). This result suggests a common KBM ancestor in a primitive NHEJ complex that may have diverged to distinct KBM motifs while the repair process complexity increased. In Saccharomyces cerevisiae, Sir4 is a structural component of a histone deacetylase complex that establishes telomeric silent chromatin. Interestingly, the crystal structure between the vWA domain of yKu80 and a Sir4 peptide was recently reported (Chen et al., 2018) (Fig. 5A). Sir4 forms an amphipathic helix that interacts with a hydrophobic pocket of the yKu80 vWA. Strikingly, the Sir4-KBM adopts a similar position compared to the APLF KBM with human $\mathrm{Ku}$, and some conserved hydrophobic residues of Ku80 are involved in both binding sites although the two KBMs bind with a reverse $\mathrm{N}$-ter towards C-ter orientation (Fig. 5A and B). Therefore, it appears that two evolutionary distant proteins involved in transactions with histones share a similar mode of binding to the yeast and human $\mathrm{Ku}$ heterodimer (Chen et al., 2018; Corbeski et al., 2018).

The apparent multitask attribute of APLF in DSB repair contrasts with a minor repair defect upon APLF depletion in human cells (Bekker-Jensen et al., 2007; Grundy et al., 2013; Iles et al., 2007; Macrae et al., 2008). Even though the Ku-APLF interaction helps recruit XRCC4 to damaged sites (Grundy et al., 2013), we showed that a Ku80 mutation that prevents APLF binding did not abolish XRCC4 recruitment at DSBs and only partially sensitizes to IR. Since $\mathrm{XLF}$ recruitment to its own binding site on Ku80 is independent of APLF, XLF interaction with XRCC4 by their head domains (see paragraph below) may compensate for the absence of APLF in recruiting XRCC4 to DSBs (Nemoz et al., 2018). In this view, the intricacy of protein-protein and protein-DNA interactions within the NHEJ machinery is an advantage guaranteeing a robust DSB repair activity even in the presence of defects in some individual components.

\subsection{XLF/Cernunnos}

XRCC4-Like Factor (XLF), also called Cernunnos, was discovered independently in 2006 by functional cDNA cloning through complementation of cells from an immunodeficient patient, and by yeast two-hybrid screening for XRCC4 partners ((Ahnesorg et al., 2006; Buck et al., 2006); see (Menon and Povirk, 2017) for a recent review). Human XLF-deficient cells are radiosensitive and exhibit impaired end-joining and V(D)J recombination activities, although lymphocyte development is only mildly affected in $\mathrm{XLF}^{-/}$ mice models (Li et al., 2008; Vera et al., 2012). This indicates an important role for XLF in NHEJ, but suggests the existence of compensatory mechanisms for XLF deficiency in particular situations (reviewed in (Menon and Povirk, 2017)) (see sections 4.3 and 5.1). Despite low sequence homology, XLF and XRCC4 display structural similarity with an amino-terminal globular head domain followed by a coiled-coil stalk required for homodimerization of each protein (Andres et al., 2007; Junop et al., 2000; Li et al., 2007) and for XRCC4 to interact with Lig4 (Sibanda et al., 2001; Wu et al., 2009).

XLF physically interacts with both components of the NHEJ ligation complex. First, XLF and XRCC4 interact together via their head domains and tend to form filaments of alternating homodimers in vitro, as established by structural studies (Andres et al., 2012; Hammel et al., 2011; Malivert et al., 2010; Ropars et al., 2011; Wu et al., 2011)(reviewed in (Mahaney et al., 2013)). Filamentous structures containing XRCC4, XLF and Lig4 seemed to spread from Ku-bound DNA ends at DSBs in cells as seen by superresolution microscopy (Reid et al., 2015). Second, XLF is able to coimmunoprecipitate with Lig4 fragments expressed in human cells in an XRCC4-independent manner and through an interaction requiring the BRCT1 domain of Lig4 (Wu et al., 2009).

Nevertheless, XLF recruitment to DSBs primarily relies on its interaction with Ku (Yano et al., 2007, 2011), even though the XRCC4-Lig4 complex stabilizes assembled NHEJ factors (Wu et al., 2007; Yano and Chen, 2008). The Ku-XLF interface involves the very C-terminus of XLF, as deletion of its last ten residues completely abolished its co-immunoprecipitation with Ku as well as its recruitment at laser-induced DSBs in living cells (Yano et al., 2011). The C-terminal region of XLF was independently characterized as a Ku-binding motif through sequence homology with the KBM found in APLF (Grundy et al., 2013). This notion was subsequently refined into $A$ and $X$ variants of KBM motifs. The highly conserved Pro-X-Trp sequence found in the A-KBM is changed into a conserved phenylalanine residue in the Ku-binding motif of XLF (hereinafter referred as X-KBM) (Fig. 2). Moreover, the presence of both an A-KBM and an X-KBM in tandem at the C-terminus of WRN (see below section 5.2) that cooperatively interact with the $\mathrm{Ku}$ heterodimer further suggests distinct binding sites in Ku for these two KBMs (Grundy et al., 2016). Recently, we definitely established the existence of separate binding sites for both A-KBM and X-KBM by determining their crystal structures in complex with the $\mathrm{Ku}$ heterodimer bound to DNA (Nemoz et al., 2018) (Fig. 4A and B). While the A-KBM interacts with a pocket positioned at the periphery of the Ku80 vWA domain, in agreement with previous biochemical and cellular data obtained with Ku80 point mutants ((Grundy et al., 2013) see above), the X-KBM binds unexpectedly to an internal site of the Ku80 vWA domain, resulting in a substantial outward rotation of this domain which is moved apart from the remainder of the Ku heterodimer (Nemoz et al., 2018) (Fig. 5C). Both the A-KBM and the X-KBM can independently interact with $\mathrm{Ku}$, but the functional consequences of the unprecedented open conformation of $\mathrm{Ku}$ elicited by X-KBM binding are still unclear and deserve further investigation. Nonetheless, the accurate delineation of the Ku-XLF interface may help define at the molecular level 

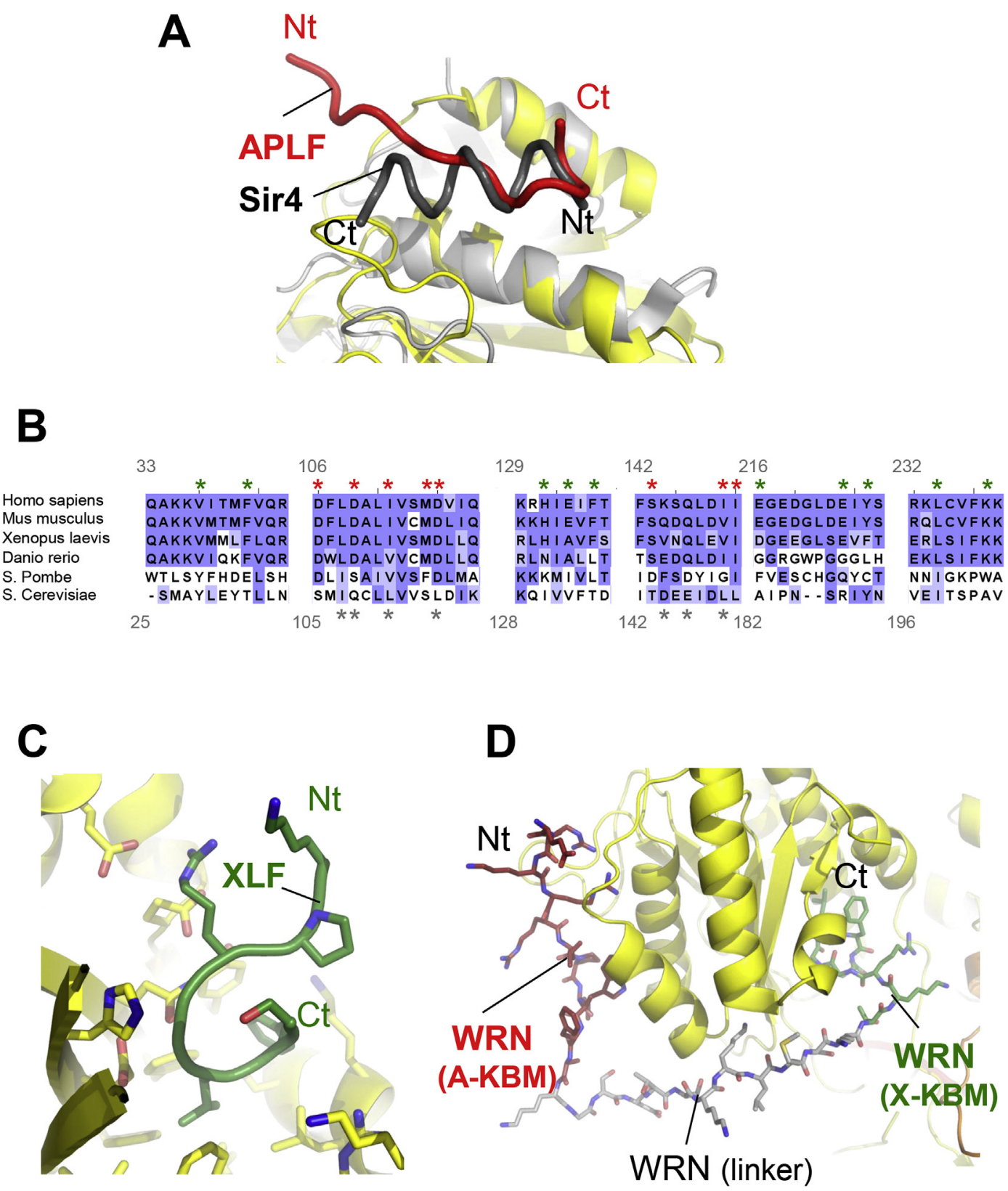

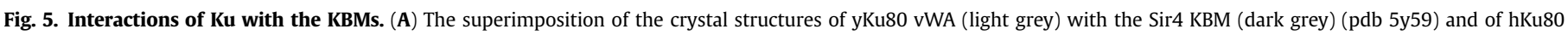

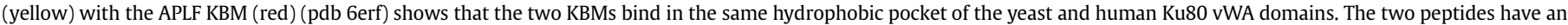

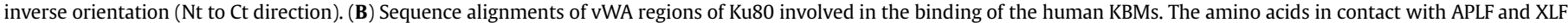

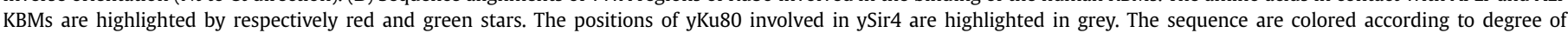

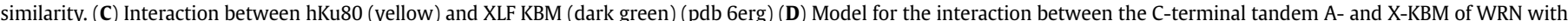
Ku80 by positioning the two KBMs in the positions observed with APLF and XLF KBMs, respectively.

the role of XLF in the NHEJ process that is still not fully understood. XLF stabilizes the synapsis of DNA ends mediated by DNA-PK and XRCC4-Lig4 (Cottarel et al., 2013), a single XLF homodimer being sufficient in a reconstituted reaction in vitro (Graham et al., 2018). XLF has been shown to activate Lig4 by different mechanisms including direct interaction with XRCC4-Lig4-DNA complexes that may result in promotion of Lig4 readenylation (Riballo et al., 2008) and stimulation of Lig4 activity, especially on incompatible DNA ends (Gu et al., 2007; Hentges et al., 2006; Lu et al., 2007; Tsai et al., 2007). Alternatively, but not exclusively, the ability of XLF-XRCC4 filaments to bridge and align DNA molecules was also proposed as a mode of action for XLF in NHEJ (Andres et al., 2012; Brouwer et al., 2016; Reid et al., 2015; Roy et al., 2012, 2015). However, an XLF-L115A mutant impaired for its ability to form DNA bridging filaments, could still support Lig4 stimulation in vitro or NHEJ and $\mathrm{V}(\mathrm{D}) \mathrm{J}$ recombination when expressed in various $\mathrm{XLF}^{-1-}$ cell lines (Roy et al., 2015). Likewise, an X-KBM mutant of XLF (L297E) impaired for its stable interaction with Ku80, exhibited also partially altered filament formation in cells while still fully functional in restoring NHEJ when expressed in XLF-deficient cells (Nemoz et al., 2018). These results clearly suggest the existence of backup processes that can compensate for defective XRCC4-XLF filaments. 


\subsection{PAXX}

PAXX (XLS or C9orf142) was first predicted as a structural paralog of XRCC4 and XLF (Ochi et al., 2015) and then identified in co-IP experiments in cell extracts as a new partner of tagged DNAPKcs (Craxton et al., 2015) or of various tagged NHEJ proteins (Xing et al., 2015). PAXX organizes as a dimer with a globular head domain highly similar to those of XLF and XRCC4, followed by a coiled-coil (Ochi et al., 2015; Xing et al., 2015). The precise function of PAXX in NHEJ is still unclear but most data indicate that PAXX is an accessory NHEJ factor under normal conditions in that PAXX deficiency leads to no or mild cell sensitivity to DNA breakage (Craxton et al., 2015; Dewan et al., 2018; Kumar et al., 2016; Lescale et al., 2016; Ochi et al., 2015; Tadi et al., 2016; Xing et al., 2015) and no or mild phenotypes in mice regarding IR sensitivity or immune defects (Abramowski et al., 2017; Balmus et al., 2016; Gago-Fuentes et al., 2018; Liu et al., 2017). Nevertheless, several data demonstrate that PAXX has overlapping functions with XLF during mice development since each single knock-out has no phenotype while the double $\mathrm{KO}$ is embryonically lethal with genomic instability, neuronal apoptosis and a lymphogenesis block due to a severe defect in V(D)J recombination (Abramowski et al., 2017; Balmus et al., 2016; Liu et al., 2017); the latter being also reproduced by double PAXX-XLF KO in pre-B and pro-B murine cells (Hung et al., 2016; Kumar et al., 2016; Lescale et al., 2016). More recently, in single DNA molecule experiments with purified components, PAXX was shown to facilitate the (XRCC4-XLF-Lig4)-dependent synapsis of DNA ends bound to DNA-PK (Wang et al., 2018). In addition, PAXX, XLF and XRCC4 N-termini interact with a subdomain of DNA Pol $\lambda$ and promote its recruitment to laser tracks in cells (Craxton et al., 2018).

PAXX, but not a truncated form lacking the C-terminus, interacts with $\mathrm{Ku}$ in complex with DNA in vitro, but not with Ku or DNA separately (Hung et al., 2016; Ochi et al., 2015; Roy et al., 2015; Xing et al., 2015), and is recruited via Ku in cells to nuclear laserdamaged sites (Liu et al., 2017; Ochi et al., 2015; Xing et al., 2015). Notably, the C-terminus contains a KBM-like pattern that diverges enough from the A- and X-KBM consensus to define a third KBM class of motifs that we name P-KBM (Fig. 2). Mutations in this motif, especially F201A alone or combined with V199A in human, or V200A/F202A in mouse, compromised PAXX binding to Ku-DNA, synapsis facilitation in vitro, nuclear localization and recruitment at laser damaged-sites in cells, and complementation of IR sensitivity in PAXX KO DT40 cells or V(D)J defects in XLF and PAXX double KO lymphocytes (Hung et al., 2016; Lescale et al., 2016; Ochi et al., 2015; Wang et al., 2018; Xing et al., 2015). What is the target site of the P-KBM in Ku? The observation of ternary Ku-PAXX-XLF complexes on DNA suggests that XLF and PAXX may bind $\mathrm{Ku}$ simultaneously on distinct sites. Indeed, Tadi et al. showed that PAXX is able to bind Ku70 homodimers with the same affinity as Ku heterodimers and with the same PAXX C-terminal requirement (Tadi et al., 2016). This supports distinct binding sites on Ku for PAXX (Ku70) and XLF (Ku80) and thereby, distinct X- and P-KBM classes. Interestingly, RRR177-179AAA mutations in the C-terminus upstream of this motif also impact association with Ku in co-IP and with Ku-DNA in EMSA (Tadi et al., 2016; Xing et al., 2015). PAXX association with Ku-DNA requires a protruding single-stranded or double-stranded DNA (Tadi et al., 2016) and interaction with $\mathrm{Ku}-$ DNA in ITC experiments of a PAXX peptide containing the P-KBM requires extension of the sequence to these RRR residues ((Tadi et al., 2016), unpublished results), while a peptide restricted to PKBM accumulated very weakly at localized laser DNA damage (Grundy et al., 2016). These data suggest that the optimal conditions for PAXX engagement in NHEJ may be its concomitant association with Ku through the P-KBM and with DNA through at least the C-terminal region upstream of the P-KBM.

\subsection{The X-family DNA polymerases}

Three of the four X-family DNA polymerases are implicated in DSB processing associated with NHEJ, namely DNA polymerase lambda (Pol $\lambda$ ), DNA polymerase mu (Pol $\mu$ ) and the terminal deoxynucleotidyl transferase (TdT) (for review (Ramsden and Asagoshi, 2012),). While the two former enzymes are ubiquitously expressed, expression of TdT is restricted to early developing lymphocytes when its full template-independent DNA synthesis capacity ensures diversification of immunoglobulins and T-cell receptors during the $V(D) J$ recombination process (Loc'h and Delarue, 2018). It has been proposed that the three polymerases distribute over a gradient of template strand dependence, with Pol $\lambda$ being template dependent, Pol $\mu$ intermediate and TdT template independent (Andrade et al., 2009; Nick McElhinny et al., 2005; Ramsden, 2010). In addition, Pol $\mu$ and TdT have the intrinsic property to promote close physical association of the two broken ends (Gouge et al., 2015) and to incorporate ribonucleotides during NHEJ at a subset of DNA ends (Pryor et al., 2018). All three polymerases possess an Nterminal BRCT domain (Fig. 2), that was originally found in the Cterminus of the breast cancer associated BRCA1 protein and that is known to promote phosphorylation-dependent and independent protein interactions (Leung and Glover, 2011).

These X-family DNA polymerases most likely enter the NHEJ mechanism through interaction with $\mathrm{Ku}$, possibly together with DNA, as inferred from co-IP or EMSA experiments with purified proteins, which also pointed out a similar requirement of the BRCT domain for interaction of each of the three polymerases with the Ku-DNA complex (Craxton et al., 2018; Ma et al., 2004; Mahajan et al., 1999). Additional contacts with XRCC4-Lig4 may also favor full activity in NHEJ (Boubakour-Azzouz et al., 2012; Mahajan et al., 2002). Sequence and structure comparisons reveal a conserved pattern in the $\alpha$-helix 1 of the three BRCT domains containing $R$ residues together with $\mathrm{F}$ and $\mathrm{L}$ hydrophobic residues that are solvent exposed and may support interactions with protein partners (Fig. 2) (DeRose et al., 2007; Mueller et al., 2008). Indeed, R, F or L to A substitutions at the corresponding positions in Pol $\mu$ (R43, F46, L50) and Pol $\lambda$ (R57, L60) compromised interaction with the KuXRCC4-Lig4-DNA complex and NHEJ function in vitro (DeRose et al., 2007; Mueller et al., 2008). In addition, combined R57A/L60A mutation of Pol $\lambda$ abolished interaction with Ku-DNA (Craxton et al., 2018). Extending the latter result suggests that, in all three polymerases, this pattern could define a common KBM of a specific class that we propose to call the BRCT-KBM (B-KBM) (Fig. 2). The functionality of this KBM awaits confirmation with dedicated biophysical, biochemical or structural experiments with purified components.

\section{Proteins containing several KBMs}

Among Ku partners and apart from the proteins described above containing only one class of KBM, the following two proteins have been characterized as containing a mixture of two types of KBMs or KBM-like motifs.

\subsection{CYREN/MRI}

MRI (CYREN or C7orf49) is a small protein (157 aa) that was initially identified as able to suppress resistance to retroviral infection of a mutant hamster cell line when overexpressed and was shown to be required for HIV-1 viral vector infection in human cells (Agarwal et al., 2006). It was then discovered that this protein was able to bind to Ku and that among the three isoforms resulting 
from alternative splicing, only the two isoforms sharing the 46 aa $\mathrm{N}$-terminus interacted with $\mathrm{Ku}$ (Slavoff et al., 2014). The MRI sequence contains an N-terminal A-KBM like motif (Fig. 2). Grundy et al. showed that the corresponding peptide bound to $\mathrm{Ku}$ in vitro with the same affinity than the equivalent peptides bearing an AKBM in APLF and in WRN. Accordingly, a W16A mutation abolished this binding and an excess of the APLF A-KBM peptide displaced it from $\mathrm{Ku}$, supporting that all these A-KBM motifs target the same site in the vWA domain of Ku80 (Grundy et al., 2016). Likewise, an L68R mutation in the APLF binding site of Ku80 reduced MRI AKBM peptide recruitment to laser-damaged sites in cells (Grundy et al., 2016). Arnoult et al. confirmed the Ku-binding property of the MRI N-terminal A-KBM, but also identified a new function of MRI as a cell-cycle regulator of NHEJ (CYREN) acting as an NHEJ inhibitor at deprotected telomeres in the S and G2 phases (Arnoult et al., 2017). Interestingly, NHEJ inhibition relies on CYREN binding to Ku since mutation of P14A or W16A in the A-KBM prevents this function (Arnoult et al., 2017), suggesting that a cell-cycle dependent modification of either or both partners would prevent CYREN binding to $\mathrm{Ku}$ in $\mathrm{G} 1$.

Sequence inspection shows that the C-terminus of the longest MRI isoform may contain a X-KBM like pattern (Fig. 2). However, the corresponding peptide does not interact with $\mathrm{Ku}$ in vitro and is cytoplasmic in cells (Grundy et al., 2016). These data suggest that only the A-KBM at the N-terminus actually interacts with $\mathrm{Ku}$. In agreement with this notion, only immunoprecipitation with the MRI N-terminus retrieves $\mathrm{Ku}$ and associated NHEJ proteins from cell lysates while the MRI C-terminal fragment rather attracts DDR proteins including ATM, KAP1 and the MRN complex (Hung et al., 2018). This specificity of N- and C-termini in protein interactions likely contributes to stabilize both NHEJ and DDR proteins at damaged chromatin in cells as shown with full length MRI (Hung et al., 2018). In contrast to CYREN/MRI as an NHEJ inhibitor, this factor was more recently found to be required for optimal resistance to ionizing radiation and class-switch recombination and to overcome XLF deficiency in NHEJ, as revealed by the embryonic lethality of the XLF-MRI double knock-out mutant and the associated profound defect in V(D)J recombination (Hung et al., 2018). Therefore, deciphering what controls CYREN/MRI negative and positive roles in NHEJ awaits further exploration, as well as establishing the precise molecular contacts engaged by the C-terminal KBM-like motif.

\section{2. $W R N$}

The Werner protein (WRN) belongs to the RecQ-like family of DNA helicases that fulfill important cellular functions involved in DNA transactions and genome maintenance (Croteau et al., 2014). Unlike other RecQ-like helicase members, WRN exhibits an additional 3' $\rightarrow$ ' exonuclease activity driven by its amino-terminal domain. Loss-of-function mutations in the WRN gene are causative of Werner Syndrome (WS), an autosomal recessive inherited disorder typified by premature aging commonly featuring bilateral cataract, graying and loss of hair, atrophic skin, atherosclerosis and cancer predisposition (Oshima et al., 2017; Shamanna et al., 2017; Yokote et al., 2017). At the cellular level, WS cells exhibit a slow proliferation rate, telomere maintenance deficiency, genomic instability and sensitivity to genotoxic agents such as ROS inducers and Top1 inhibitors (Rossi et al., 2010).

WRN generally appears in the top list of Ku partners found in large-scale interactome analyses (Brown et al., 2015; Hein et al., 2015; Lachapelle et al., 2011; Xing et al., 2015). Ku-WRN protein interaction was first characterized in the early 2000s by Bohr's and Comai's groups. The interaction was initially demonstrated by pulldown and co-immunoprecipitation assays and was shown to specifically stimulate WRN exonuclease activity (Cooper et al., 2000; Li and Comai, 2000). Early observations with truncated proteins revealed a physical interaction between both N-terminal regions of WRN (WRN ${ }^{1-388}$ or even $\mathrm{WRN}^{1-50}$ ) and of Ku80 (Ku801-276) (Li and Comai, 2000, 2001; Li and Comai, 2001). Further mapping of Ku-WRN interface by co-IP and far-western analysis revealed that the WRN N-terminus $\left(\mathrm{WRN}^{1-368}\right)$ interacted instead with the carboxy-terminal region of Ku70 $\left(\mathrm{Ku} 70^{543-609}\right)$, while the WRN C-terminus (WRN $\left.{ }^{940-1432}\right)$ interacted with the Ku80 C-terminus of (Ku80 $\left.{ }^{572-732}\right)$ (Karmakar et al., 2002). A way to reconcile these results regarding the WRN N-terminus is to consider that the amino-terminal exonuclease domain of WRN would be able to interact with both the Ku70 C-terminus and the Ku80 N-terminus; a likely possibility owing to spatial proximity of these domains in the crystal structure of Ku (Walker et al., 2001). Notably, the finding of an A-KBM at the N-terminus of WRN, which was critical for the binding to the N-terminal vWA domain of Ku80 and for the stimulation of WRN exonuclease activity by Ku, further supports this model (Grundy et al., 2016) (Fig. 2). However, the presence of two additional A- and X-KBMs in tandem at the very $C$-terminus of WRN that were able to bind cooperatively to the N-terminal vWA domain of Ku80 makes the understanding of the Ku-WRN interface more puzzling (Grundy et al., 2013, 2016) (Fig. 2). The observed cooperative binding agrees well with the size of this C-terminal tandem KBM, which is consistent with a simultaneous interaction of both motifs with their respective binding sites on Ku80, thus allowing to consider this tandem KBM as a single larger binding motif (Nemoz et al., 2018) (Fig. 5D). Adding further complexity to the picture, WRN has been described to form dimers or trimers in solution and tetramers when bound to DNA substrates mimicking replication forks (Compton et al., 2008; Huang et al., 2000), while the exonuclease domain alone was shown to oligomerize as hexamers (Perry et al., 2006; Xue et al., 2002). This raises the possibility that Ku-WRN complexes may take different configurations by engaging different regions of WRN depending on which function is solicited. More specifically, the bivalency, at least, of WRN towards Ku80 allows proposing a role for WRN in bridging two Ku heterodimers bound at DNA ends. Such a potential role of WRN in synapsis requires validation. Furthermore, the interaction between $\mathrm{Ku}$ and WRN is probably not restricted to already identified KBMs, as nonsynonymous polymorphisms at unrelated residues could also alter Ku-WRN affinity (Gagne et al., 2016). Further biochemical, cellular and structural analyses are thus needed to definitely delineate the Ku-WRN interface.

From a functional point of view, Ku-WRN interaction was found to be essential for optimal DSB repair rate, as assessed by $\gamma \mathrm{H} 2 \mathrm{AX}$ foci formation and decrease following $\gamma$-ray irradiation of G0/G1arrested human cells (Grundy et al., 2016). At the molecular level, WRN appeared required to prevent large deletion at DNA ends in in vitro end-joining reactions with linearized plasmids as substrates (Oshima et al., 2002). More recently, this DNA end protection function was shown to rely on non-catalytic activities of WRN operating by suppressing the recruitment of MRE11 and CtIP at breaks, thus limiting alternative end-joining (Shamanna et al., 2016). On the other hand, both helicase and exonuclease activities of WRN were required to promote c-NHEJ, hence suggesting a role for WRN in regulating DSB repair pathway choice. Be that as it may, the tight interaction between Ku and WRN only modestly translates into effects at the level of cell survival to DSB induction as WRNdeficient cells exhibit a moderate, if any, sensitivity to ionizing radiation, radiomimetic compounds or Top2 inhibitors (Fujiwara et al., 1977; Gebhart et al., 1988; Imamura et al., 2002; Yannone et al., 2001)). WRN should then be regarded as an accessory factor for NHEJ. Moreover, the little investigated potential role of WRN 
in other Ku cellular functions deserves further investigations.

\section{Comments on KBMs and KBM-binding sites on Ku}

In addition to proteins whose Ku-interacting motifs have been precisely characterized or strongly suspected (Fig. 2), numerous other proteins have been proposed to be Ku partners (for a recent extensive list, see (Fell and Schild-Poulter, 2015)). For example and to stay in the field of NHEJ, direct interactions with Ku have been suggested for XRCC4 (Mari et al., 2006), LIG4 BRCT1 (Costantini et al., 2007), TDP1 (Heo et al., 2015) or RAG1 (Raval et al., 2008). Precise mapping of the corresponding interaction motifs awaits further mutagenesis or crystallography experiments. It is conceivable that among these partners, interaction sites will fall into the types of Ku-binding motifs already characterized or into new classes still to be defined.

It is striking that several KBMs are adjacent to reported DNA binding sites, as in PAXX and XLF, and that mutations in the latter sites compromise engagement of the corresponding protein in NHEJ (Nemoz et al., 2018; Tadi et al., 2016). This may explain the weak interactions measured between Ku-DNA and the corresponding KBMs when separated from the adjacent DNA binding sites. The conjoined binding to DNA and Ku may ensure proper selection of situations requiring these NHEJ factors on damaged DNA. Another striking feature is that several KBMs are located in unstructured portions of the proteins (except B-KBM in BRCT domains) and rather at distal C- and/or N-terminal positions (Fig. 2). From an anchor point on Ku that is central regarding DNA ends, this likely allows protein mobility in a wide spatial sphere to ensure optimal structural flexibility and thereby enzymatic adaptation to repair the largest range of DSB configurations (Hammel et al., 2016; Pannunzio et al., 2017).

The prevalent model for the NHEJ process proposes the concomitant binding of most of the NHEJ components, rapidly building a multitask supra-molecular complex on the Ku anchor
(Yano and Chen, 2008) (Figs. 1 and 6). This explains for example that in addition to DNA-PK, several components of the ligation complex concurrently contribute to initial (DNA-ends tethering) and final (DNA-ends joining) NHEJ steps (Cottarel et al., 2013; Graham et al., 2016; Wang et al., 2018). Demonstration of distinct protein binding sites on Ku supports the model of a Ku-based NHEJ supra-molecular complex (Nemoz et al., 2018). Indeed, distinct binding sites have been precisely positioned on human Ku80 for APLF, XLF, WRN and DNA-PKcs. We anticipate that Ku70 may harbor sites equivalent to APLF- and XLF-binding sites of Ku80, from inspection of the broad Ku70-Ku80 symmetry in the Ku heterodimer structure (Fig. 4A) and based on biochemical data implicating Ku70 in the interactions with some NHEJ players (Karmakar et al., 2002; Tadi et al., 2016).

Several KBM binding sites on $\mathrm{Ku}$ can be occupied simultaneously. For example, we proposed that the C-terminus of WRN bearing a tandem of A- and X-KBMs may conjointly contact Ku80 at the APLF and XLF binding sites (Nemoz et al., 2018) (Fig. 5D). Also, since more than one partner is able to bind to each of these KBM distinct sites, the occupancy of these sites must be finely tuned. It may rely non-exclusively on the respective affinities of KBMs for $\mathrm{Ku}$, on additional interaction points with DNA, Ku or other close NHEJ components, and on regulation of the local protein turnover during the NHEJ process. Regarding regulation of interactions with $\mathrm{Ku}$ by post-translational modifications, a key player is likely the protein kinase activity of DNA-PKcs. For example, DNA-PKcs regulates the association of the ligation complex with Ku via XRCC4 phosphorylation followed by FBW7-dependent ubiquitination (Zhang et al., 2016). Also, DNA-PKcs activity regulates the transition from loose to tight synapsis of DNA-ends (Graham et al., 2018) and DNA-PKcs autophosphoryation promotes its dissociation from $\mathrm{Ku}$ and DNA through structural changes (Dobbs et al., 2010).

To add to the complexity of the interaction network on the $\mathrm{Ku}$ hub, we have recently characterized an outward swing of the Ku80 vWA domain upon XLF binding (Nemoz et al., 2018) (Figs. 4Aand

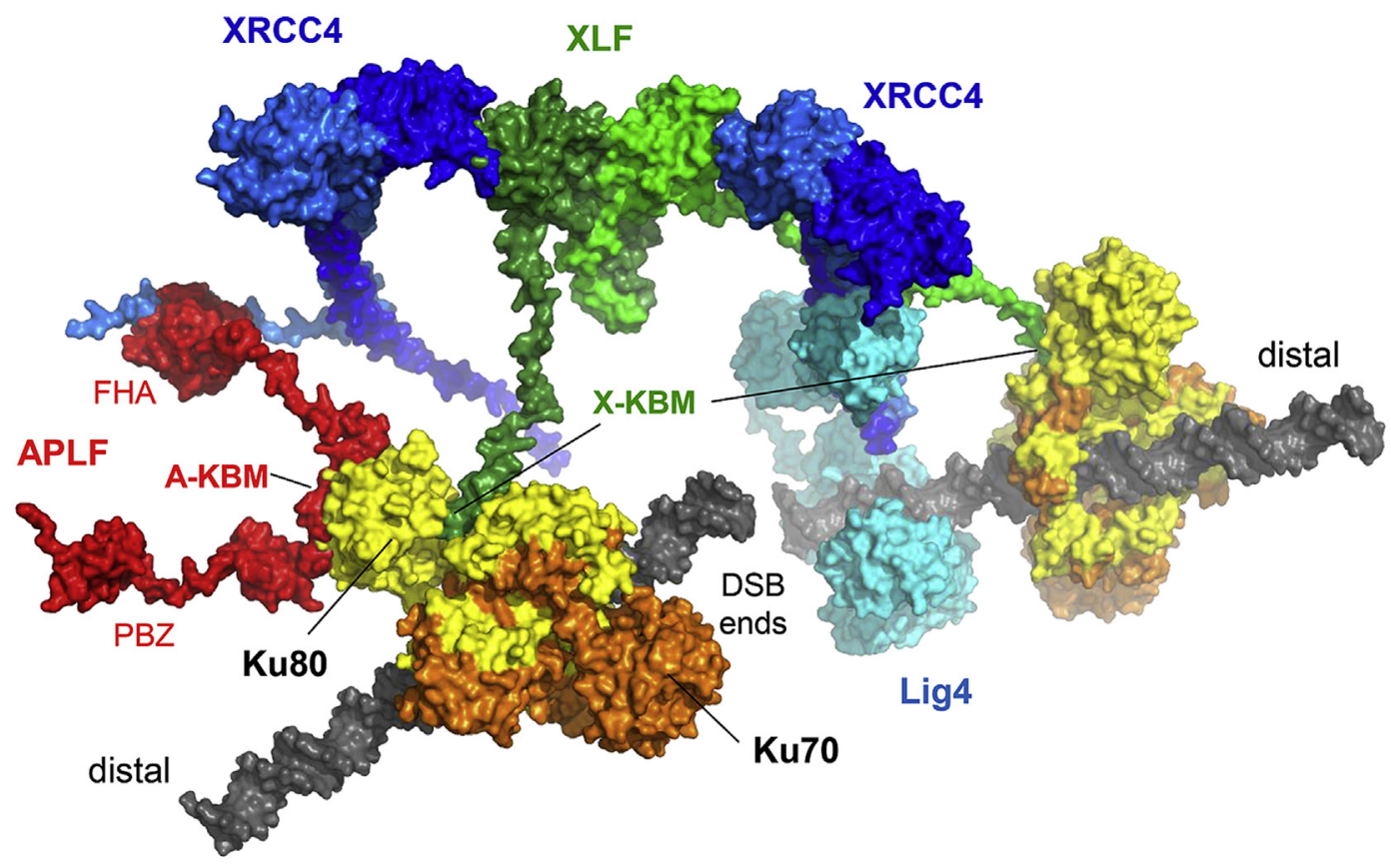

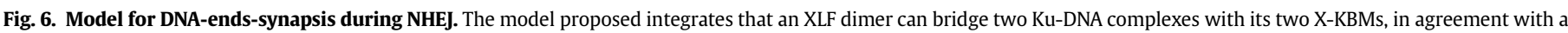

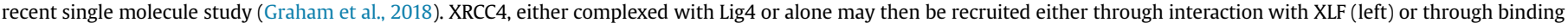

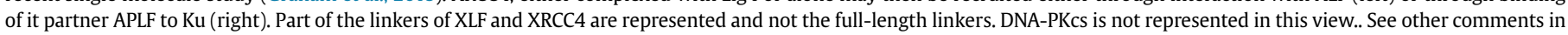
section 7. 
5C). It remains to establish if this movement plays a role in the protein network within the NHEJ complex, for example by strengthening an interaction or enrolling a new dancer in the NHEJ choreography.

Considering that Ku-DNA is the hub of the NHEJ network, it is surprising that no Ku mutant has been reported in severe combined immunodeficiency human syndromes, in contrast to mutants in $\mathrm{Ku}$ partners (Woodbine et al., 2014). Although $\mathrm{Ku}$ is essential in humans (Li et al., 2002), viable mutations in the KBMs-binding sites would still be expected. The explanation may lie in the fact that all of the Ku binders also engage interactions with at least one other component of the NHEJ machinery that may compensate for a mutation in a single KBM-binding site in $\mathrm{Ku}$. As a result, we found that only cells combining several mutant KBM-binding sites in $\mathrm{Ku}$ display noticeable radiosensitive phenotype (Nemoz et al., 2018).

\section{Bring them all together!}

From the current biochemical and structural data, it is possible to build a model of the synapsis complex at DNA ends (Fig. 6). Although $\mathrm{Ku}$ sliding on DNA from the ends has been described in vitro (de Vries et al., 1989), a precise assessment from highresolution images rather favors a dominant configuration with one Ku dimer at each DNA end (Britton et al., 2013). Two DNA-PKcs facing each other may help juxtaposing the DNA ends (Meek et al., 2007) (not represented in Fig. 6). Interestingly, since DNA-PKcs binds to $\mathrm{Ku}$ on the surface facing the DNA end, the opposite face of $\mathrm{Ku}$ is free to contact the KBMs of APLF and XLF (Fig. 4). Together with these opposite positions, the distal location of the KBM in XLF and the mostly unstructured conformation of APLF concurrently prevent steric hindrance with DNA-PKcs and allow concomitant gathering of these partners onto Ku-DNA (Fig. 6). Recent experiments based on single-molecule fluorescence imaging indicate that a single XLF homodimer is recruited on immobilized DNA fragments to achieve a transition from a long-range synaptic complex (depending on $\mathrm{Ku}$ and DNA-PKcs) to a short-range synaptic complex (depending also on XRCC4 and Lig4) in which DNA ends are tightly aligned and prone to ligation (Graham et al., 2016, 2018). These results are in line with other experiments using defined purified NHEJ factors and establishing a transition from a Ku- and DNA-PKcs-dependent loose synaptic complex to a more stable one upon stepwise addition of PAXX and XRCC4-Lig4-XLF proteins (Wang et al., 2018). Importantly, within an XLF dimer, the ability of both protomers to interact with XRCC4 was required to strengthen the synapsis cohesion (Graham et al., 2018). Thus, it is conceivable that in the synaptic complex, both XLF protomers contact two Ku80 subunits through their X-KBM, one on each side of the break, and interact simultaneously with two XRCC4 dimers (Fig. 6). In this context, XLF may also contact DNA through the DNA binding domain adjacent to the KBMs (Andres et al., 2007; Lu et al., 2007). APLF binding to Ku favors XRCC4 integration into the complex, through interactions of its $\mathrm{N}$-terminal globular head with its cognate in XLF, in addition to interactions with Ku (Mari et al., 2006), DNA-PKcs (Hsu et al., 2002; Leber et al., 1998) and/or DNA (Modesti et al., 1999). Interestingly, the position of APLF favors the orientation of its C-terminal PBZ and NAP1L domains towards their targets (likely parylated histones and histone dimers (Corbeski et al., 2018)) (Fig. 6). Lig4 linked to XRCC4 is indispensable for proper end-synapsis, independently of its catalytic activity (Cottarel et al., 2013; Graham et al., 2016). This property may rely on its DNA binding domain and/or supplementary contacts engaged with XLF (Wu et al., 2009), the DNA-PKcs partner Artemis (Ochi et al., 2013) or Ku (Costantini et al., 2007). Whether synapsis requires one or two Lig4 molecules is unknown. Nevertheless, since each DNA chain can be ligated independently (Ma et al., 2004), it is conceivable that one Lig4 molecule may be present at a time (Fig. 6). A symmetrical XRCC4 dimer bound to XLF and not engaged with APLF could bring the Polynucleotide Kinase/Phosphatase (PNKP) attached through its FHA domain at phospho-T233 (Aceytuno et al., 2017). Other players harboring KBMs may also consolidate end-synapsis. In this view, it is striking that combined deletion of Xlf with Paxx or Mri (and not either deletion alone) is lethal in mice and leads to profound V(D)J defect in cells, suggesting that these factors fulfill an overlapping function, that some recent data suggest as being synapsis (Hung et al., 2018; Wang et al., 2018).

Obviously, additional biochemical and structural analyses are highly awaited to elucidate the precise architecture of DNA end synapsis and the position occupied by the various NHEJ players.

\section{Acknowledgments}

The authors thank C. Mann (I2BC) for helpful discussions on the review. P.C.'s team is supported by the Ligue Nationale Contre Le Cancer (Equipe labellisée 2018) and Électricité de France (EDF, Conseil de Radioprotection). J-B.C., M.M. and P.C. are supported by ANR (CE12 2017 NHEJLIG4 grant). J-B.C. is supported by ARC program (SLS220120605310), ANR (ANR-12-SVSE8-012), INCA DomRep (PLBIO 2012-280), CEFIPRA grant 5203C and by the French Infrastructure for Integrated Structural Biology ANR-10-INBS-05. M.M.'s team is supported by the Ligue Nationale Contre Le Cancer (Equipe labellisée 2018) and grant PLBIO17-267 from the French National Cancer Institut. V.R. is supported by the Fondation ARC pour la Recherche sur le Cancer (PJA 20171206409). P.C. and M.M. are scientists from INSERM.

\section{Appendix A. Supplementary data}

Supplementary data to this article can be found online at https://doi.org/10.1016/j.pbiomolbio.2019.03.001.

\section{References}

Abramowski, V., Etienne, O., Elsaid, R., Yang, J., Berland, A., Kermasson, L., Roch, B. Musilli, S., Moussu, J.P., Lipson-Ruffert, K., Revy, P., Cumano, A., Boussin, F.D., de Villartay, J.P., 2017. PAXX and Xlf interplay revealed by impaired CNS development and immunodeficiency of double KO mice. Cell Death Differ. 25, 444-452. Aceytuno, R.D., Piett, C.G., Havali-Shahriari, Z., Edwards, R.A., Rey, M., Ye, R., Javed, F., Fang, S., Mani, R., Weinfeld, M., Hammel, M., Tainer, J.A., Schriemer, D.C., LeesMiller, S.P., Glover, J.N.M., 2017. Structural and functional characterization of the PNKP-XRCC4-LigIV DNA repair complex. Nucleic Acids Res. 45, 6238-6251.

Agarwal, S., Harada, J., Schreifels, J., Lech, P., Nikolai, B., Yamaguchi, T., Chanda, S.K., Somia, N.V., 2006. Isolation, characterization, and genetic complementation of a cellular mutant resistant to retroviral infection. Proc. Natl. Acad. Sci. U. S. A. 103, 15933-15938.

Ahel, I., Ahel, D., Matsusaka, T., Clark, A.J., Pines, J., Boulton, S.J., West, S.C., 2008. Poly(ADP-ribose)-binding zinc finger motifs in DNA repair/checkpoint proteins. Nature 451, 81-85.

Ahnesorg, P., Smith, P., Jackson, S.P., 2006. XLF interacts with the XRCC4-DNA ligase IV complex to promote DNA nonhomologous end-joining. Cell 124, 301-313.

Alt, F.W., Schwer, B., 2018. DNA double-strand breaks as drivers of neural genomic change, function, and disease. DNA Repair 71, 158-163.

Alt, F.W., Zhang, Y., Meng, F.L., Guo, C., Schwer, B., 2013. Mechanisms of programmed DNA lesions and genomic instability in the immune system. Cell 152, $417-429$.

Andrade, P., Martin, M.J., Juarez, R., Lopez de Saro, F., Blanco, L., 2009. Limited terminal transferase in human DNA polymerase $\{$ micro\} defines the required balance between accuracy and efficiency in NHEJ. Proc. Natl. Acad. Sci. U. S. A. 106, 16203-16208.

Andres, S.N., Modesti, M., Tsai, C.J., Chu, G., Junop, M.S., 2007. Crystal structure of human XLF: a twist in nonhomologous DNA end-joining. Mol. Cell 28, 1093-1101.

Andres, S.N., Vergnes, A, Ristic, D.,Wyman, C, Modesti, M.,Junop, M. 2012 A human XRCC4-XLF complex bridges DNA. Nucleic Acids Res. 40, 1868-1878. Arnaudeau, C., Lundin, C., Helleday, T., 2001. DNA double-strand breaks associated with replication forks are predominantly repaired by homologous recombination involving an exchange mechanism in mammalian cells. J. Mol. Biol. 307, 1235-1245.

Arnoult, N., Correia, A., Ma, J., Merlo, A., Garcia-Gomez, S., Maric, M., Tognetti, M., 
Benner, C.W., Boulton, S.J., Saghatelian, A., Karlseder, J., 2017. Regulation of DNA repair pathway choice in S and G2 phases by the NHEJ inhibitor CYREN. Nature $549,548-552$.

Arosio, D., Costantini, S., Kong, Y., Vindigni, A., 2004. Fluorescence anisotropy studies on the Ku-DNA interaction: anion and cation effects. J. Biol. Chem. 279, 42826-42835.

Arosio, D., Cui, S., Ortega, C., Chovanec, M., Di Marco, S., Baldini, G., Falaschi, A., Vindigni, A., 2002. Studies on the mode of Ku interaction with DNA. J. Biol. Chem. 277, 9741-9748.

Balmus, G., Barros, A.C., Wijnhoven, P.W., Lescale, C., Hasse, H.L., Boroviak, K., le Sage, C., Doe, B., Speak, A.O., Galli, A., Jacobsen, M., Deriano, L., Adams, D.J., Blackford, A.N., Jackson, S.P., 2016. Synthetic lethality between PAXX and XLF in mammalian development. Genes Dev. 30, 2152-2157.

Bekker-Jensen, S., Fugger, K., Danielsen, J.R., Gromova, I., Sehested, M., Celis, J., Bartek, J., Lukas, J., Mailand, N., 2007. Human Xip1 (C2ORF13) is a novel regulator of cellular responses to DNA strand breaks. J. Biol. Chem. 282, $19638-19643$.

Bennett, S.M., Woods, D.S., Pawelczak, K.S., Turchi, J.J., 2012. Multiple proteinprotein interactions within the DNA-PK complex are mediated by the C-terminus of Ku 80. Int J Biochem Mol Biol. 3, 36-45.

Bertrand, C., Thibessard, A., Bruand, C., Lecointe, F., Leblond, P., 2019. Bacterial NHEJ: a never ending story. Mol. Microbiol. https://doi.org/10.1111/mmi.14218.

Betermier, M., Bertrand, P., Lopez, B.S., 2014. Is non-homologous end-joining really an inherently error-prone process? PLoS Genet. 10, e1004086.

Blier, P.R., Griffith, A.J., Craft, J., Hardin, J.A., 1993. Binding of Ku protein to DNA. Measurement of affinity for ends and demonstration of binding to nicks. J. Biol. Chem. 268, 7594-7601.

Boubakour-Azzouz, I., Bertrand, P., Claes, A., Lopez, B.S., Rougeon, F., 2012. Terminal deoxynucleotidyl transferase requires KU80 and XRCC4 to promote N-addition at non-V(D)J chromosomal breaks in non-lymphoid cells. Nucleic Acids Res. 40, 8381-8391.

Britton, S., Coates, J., Jackson, S.P., 2013. A new method for high-resolution imaging of $\mathrm{Ku}$ foci to decipher mechanisms of DNA double-strand break repair. J. Cell Biol. 202, 579-595.

Brouwer, I., Sitters, G., Candelli, A., Heerema, S.J., Heller, I., Melo de, A.J., Zhang, H., Normanno, D., Modesti, M., Peterman, E.J., Wuite, G.J., 2016. Sliding sleeves of XRCC4-XLF bridge DNA and connect fragments of broken DNA. Nature 535, $566-569$.

Brown, J.S., Lukashchuk, N., Sczaniecka-Clift, M., Britton, S., le Sage, C., Calsou, P., Beli, P., Galanty, Y., Jackson, S.P., 2015. Neddylation promotes ubiquitylation and release of Ku from DNA-damage sites. Cell Rep. 11, 704-714.

Buck, D., Malivert, L., de Chasseval, R., Barraud, A., Fondaneche, M.C., Sanal, O., Plebani, A., Stephan, J.L., Hufnagel, M., le Deist, F., Fischer, A., Durandy, A., de Villartay, J.P., Revy, P., 2006. Cernunnos, a novel nonhomologous end-joining factor, is mutated in human immunodeficiency with microcephaly. Cell 124 287-299.

Cary, R.B., Peterson, S.R., Wang, J., Bear, D.G., Bradbury, E.M., Chen, D.J., 1997. DNA looping by Ku and the DNA-dependent protein kinase. Proc. Natl. Acad. Sci. U. S. A. $94,4267-4272$

Chan, D.W., Mody, C.H., Ting, N.S., Lees-Miller, S.P., 1996. Purification and characterization of the double-stranded DNA-activated protein kinase, DNA-PK, from human placenta. Biochem. Cell Biol. 74, 67-73.

Chang, H.H.Y., Pannunzio, N.R., Adachi, N., Lieber, M.R., 2017. Non-homologous DNA end joining and alternative pathways to double-strand break repair. Nat. Rev. Mol. Cell Biol. 18, 495-506.

Chanut, P., Britton, S., Coates, J., Jackson, S.P., Calsou, P., 2016. Coordinated nuclease activities counteract Ku at single-ended DNA double-strand breaks. Nat. Commun. 7, 12889.

Chen, H., Xue, J., Churikov, D., Hass, E.P., Shi, S., Lemon, L.D., Luciano, P., Bertuch, A.A., Zappulla, D.C., Geli, V., Wu, J., Lei, M., 2018. Structural insights into yeast telomerase recruitment to telomeres. Cell 172, 331-343 e313.

Compton, S.A., Tolun, G., Kamath-Loeb, A.S., Loeb, L.A., Griffith, J.D., 2008. The Werner syndrome protein binds replication fork and holliday junction DNAs as an oligomer. J. Biol. Chem. 283, 24478-24483.

Cooper, M.P. Machwe, A., Orren, D.K., Brosh, R.M., Ramsden, D., Bohr, V.A., 2000. Ku complex interacts with and stimulates the Werner protein. Genes Dev. 14, 907-912.

Corbeski, I., Dolinar, K., Wienk, H., Boelens, R., van Ingen, H., 2018. DNA repair factor APLF acts as a H2A-H2B histone chaperone through binding its DNA interaction surface. Nucleic Acids Res. 46, 7138-7152.

Costantini, S., Woodbine, L., Andreoli, L., Jeggo, P.A., Vindigni, A., 2007. Interaction of the Ku heterodimer with the DNA ligase IV/Xrcc4 complex and its regulation by DNA-PK. DNA Repair 6, 712-722.

Cottarel, J., Frit, P., Bombarde, O., Salles, B., Negrel, A., Bernard, S., Jeggo, P.A., Lieber, M.R., Modesti, M., Calsou, P., 2013. A noncatalytic function of the ligation complex during nonhomologous end joining. J. Cell Biol. 200, 173-186.

Craxton, A., Munnur, D., Jukes-Jones, R., Skalka, G., Langlais, C., Cain, K., Malewicz, M., 2018. PAXX and its paralogs synergistically direct DNA polymerase lambda activity in DNA repair. Nat. Commun. 9, 3877.

Craxton, A., Somers, J., Munnur, D., Jukes-Jones, R., Cain, K., Malewicz, M., 2015. XLS (c9orf142) is a new component of mammalian DNA double-stranded break repair. Cell Death Differ. 22, 890-897.

Croteau, D.L., Popuri, V., Opresko, P.L., Bohr, V.A., 2014. Human RecQ helicases in DNA repair, recombination, and replication. Annu. Rev. Biochem. 83, 519-552. de Villartay, J.P., 2015. Congenital defects in V(D)J recombination. Br. Med. Bull. 114,
$157-167$

de Vries, E., van Driel, W., Bergsma, W.G. Arnberg, A.C., van der Vliet, P.C., 1989. HeLa nuclear protein recognizing DNA termini and translocating on DNA forming a regular DNA-multimeric protein complex. J. Mol. Biol. 208, 65-78.

DeRose, E.F., Clarkson, M.W., Gilmore, S.A., Galban, C.J., Tripathy, A., Havener, J.M., Mueller, G.A., Ramsden, D.A., London, R.E., Lee, A.L., 2007. Solution structure of polymerase mu's BRCT Domain reveals an element essential for its role in nonhomologous end joining. Biochemistry 46, 12100-12110.

Dewan, A., Xing, M., Lundbaek, M.B., Gago-Fuentes, R., Beck, C., Aas, P.A. Liabakk, N.B., Saeterstad, S., Chau, K.T.P., Kavli, B.M., Oksenych, V., 2018. Robust DNA repair in PAXX-deficient mammalian cells. FEBS Open Bio 8, 442-448.

Dobbs, T.A., Tainer, J.A., Lees-Miller, S.P., 2010. A structural model for regulation of NHEJ by DNA-PKcs autophosphorylation. DNA Repair 9, 1307-1314.

Emerson, C.H., Bertuch, A.A., 2016. Consider the workhorse: nonhomologous endjoining in budding yeast. Biochem. Cell Biol. 1-11.

Falck, J., Coates, J., Jackson, S.P., 2005. Conserved modes of recruitment of ATM, ATR and DNA-PKcs to sites of DNA damage. Nature 434, 605-611.

Fell, V.L., Schild-Poulter, C., 2015. The Ku heterodimer: function in DNA repair and beyond. Mutat. Res. Rev. Mutat. Res. 763, 15-29.

Fujiwara, Y., Higashikawa, T. Tatsumi, M., 1977. A retarded rate of DNA replication and normal level of DNA repair in Werner's syndrome fibroblasts in culture. J. Cell. Physiol. 92, 365-374.

Gagne, J.P., Lachapelle, S., Garand, C., Tsofack, S.P., Coulombe, Y., Caron, M.C. Poirier, G.G., Masson, J.Y., Lebel, M., 2016. Different non-synonymous polymorphisms modulate the interaction of the WRN protein to its protein partners and its enzymatic activities. Oncotarget 7, 85680-85696.

Gago-Fuentes, R., Xing, M., Saeterstad, S., Sarno, A., Dewan, A., Beck, C. Bradamante, S., Bjoras, M., Oksenych, V., 2018. Normal development of mice lacking PAXX, the paralogue of XRCC4 and XLF. FEBS Open Bio 8, 426-434.

Gebhart, E., Bauer, R., Raub, U., Schinzel, M., Ruprecht, K.W., Jonas, J.B., 1988 Spontaneous and induced chromosomal instability in Werner syndrome. Hum. Genet. 80, 135-139.

Gell, D., Jackson, S.P., 1999. Mapping of protein-protein interactions within the DNAdependent protein kinase complex. Nucleic Acids Res. 27, 3494-3502.

Glickman, M.S., 2014. Double-strand DNA break repair in mycobacteria. Microbiol. Spectr. 2 https://doi.org/10.1128/microbiolspec.MGM1122-0024-2013.

Gottlieb, T.M., Jackson, S.P., 1993. The DNA-dependent protein kinase: requirement for DNA ends and association with Ku antigen. Cell 72, 131-142.

Gouge, J., Rosario, S., Romain, F., Poitevin, F., Beguin, P., Delarue, M., 2015. Structural basis for a novel mechanism of DNA bridging and alignment in eukaryotic DSB DNA repair. EMBO J. 34, 1126-1142.

Graham, T.G., Walter, J.C., Loparo, J.J., 2016. Two-stage synapsis of DNA ends during non-homologous end joining. Mol. Cell 61, 850-858.

Graham, T.G.W., Carney, S.M., Walter, J.C., Loparo, J.J., 2018. A single XLF dimer bridges DNA ends during nonhomologous end joining. Nat. Struct. Mol. Biol. 25, $877-884$.

Grundy, G.J., Moulding, H.A., Caldecott, K.W., Rulten, S.L., 2014. One ring to bring them all-The role of $\mathrm{Ku}$ in mammalian non-homologous end joining. DNA Repair 17, 30-38.

Grundy, G.J., Rulten, S.L., Arribas-Bosacoma, R., Davidson, K., Kozik, Z., Oliver, A.W. Pearl, L.H., Caldecott, K.W., 2016. The Ku-binding motif is a conserved module for recruitment and stimulation of non-homologous end-joining proteins. Nat. Commun. 7, 11242.

Grundy, G.J., Rulten, S.L., Zeng, Z., Arribas-Bosacoma, R., Iles, N., Manley, K., Oliver, A., Caldecott, K.W., 2013. APLF promotes the assembly and activity of non-homologous end joining protein complexes. EMBO J. 32, 112-125.

Gu, J., Lu, H., Tsai, A.G., Schwarz, K., Lieber, M.R., 2007. Single-stranded DNA ligation and XLF-stimulated incompatible DNA end ligation by the XRCC4-DNA ligase IV complex: influence of terminal DNA sequence. Nucleic Acids Res. 35, 9605-9619.

Gu, Y., Jin, S., Gao, Y., Weaver, D.T., Alt, F.W., 1997. Ku70-deficient embryonic stem cells have increased ionizing radiosensitivity, defective DNA end-binding activity, and inability to support V(D)J recombination. Proc. Natl. Acad. Sci. U. S. A 94, 8076-8081.

Hammel, M., Rey, M., Yu, Y., Mani, R.S., Classen, S., Liu, M., Pique, M.E., Fang, S. Mahaney, B., Weinfeld, M., Schriemer, D.C., Lees-Miller, S.P., Tainer, J.A., 2011. XRCC4 interactions with XRCC4-like factor (XLF) create an extended grooved scaffold for DNA ligation and double-strand break repair. J. Biol. Chem. 286, 32638-32650.

Hammel, M., Yu, Y., Mahaney, B.L., Cai, B., Ye, R., Phipps, B.M., Rambo, R.P., Hura, G.L., Pelikan, M., So, S., Abolfath, R.M., Chen, D.J., Lees-Miller, S.P., Tainer, J.A., 2010 $\mathrm{Ku}$ and DNA-dependent protein kinase dynamic conformations and assembly regulate DNA binding and the initial non-homologous end joining complex. J. Biol. Chem. 285, 1414-1423.

Hammel, M., Yu, Y., Radhakrishnan, S.K., Chokshi, C., Tsai, M.S., Matsumoto, Y. Kuzdovich, M., Remesh, S.G., Fang, S, Tomkinson, A.E., Lees-Miller, S.P. Tainer, J.A., 2016. An intrinsically disordered APLF links Ku, DNA-PKcs, and XRCC4-DNA ligase IV in an extended flexible non-homologous end joining complex. J. Biol. Chem. 291, 26987-27006.

Hein, M.Y., Hubner, N.C., Poser, I., Cox, J., Nagaraj, N., Toyoda, Y., Gak, I.A. Weisswange, I., Mansfeld, J., Buchholz, F., Hyman, A.A., Mann, M., 2015 A human interactome in three quantitative dimensions organized by stoichiometries and abundances. Cell 163, 712-723.

Hentges, P., Ahnesorg, P., Pitcher, R.S., Bruce, C.K., Kysela, B., Green, A.J., Bianchi, J. Wilson, T.E., Jackson, S.P., Doherty, A.J., 2006. Evolutionary and functional 
conservation of the DNA non-homologous end-joining protein, XLF/Cernunnos. J. Biol. Chem. 281, 37517-37526.

Heo, J., Li, J., Summerlin, M., Hays, A., Katyal, S., McKinnon, P.J., Nitiss, K.C., Nitiss, J.L., Hanakahi, L.A., 2015. TDP1 promotes assembly of non-homologous end joining protein complexes on DNA. DNA Repair 30, 28-37.

Hsu, H.L., Yannone, S.M., Chen, D.J., 2002. Defining interactions between DNA-PK and ligase IV/XRCC4. DNA Repair 1, 225-235.

Huang, S., Beresten, S., Li, B., Oshima, J., Ellis, N.A., Campisi, J., 2000. Characterization of the human and mouse WRN 3'->5' exonuclease. Nucleic Acids Res. 28, 2396-2405.

Hung, P.J., Chen, B.R., George, R., Liberman, C., Morales, A.J., Colon-Ortiz, P., Tyler, J.K., Sleckman, B.P., Bredemeyer, A.L., 2016. Deficiency of XLF and PAXX prevents DNA double-strand break repair by non-homologous end joining in lymphocytes. Cell Cycle 16, 286-295.

Hung, P.J., Johnson, B., Chen, B.R., Byrum, A.K., Bredemeyer, A.L., Yewdell, W.T., Johnson, T.E., Lee, B.J., Deivasigamani, S., Hindi, I., Amatya, P., Gross, M.L., Paull, T.T., Pisapia, D.J., Chaudhuri, J., Petrini, J.J.H., Mosammaparast, N., Amarasinghe, G.K., Zha, S., Tyler, J.K., Sleckman, B.P., 2018. MRI is a DNA damage response adaptor during classical non-homologous end joining. Mol. Cell 71, $332-342$.

Iles, N., Rulten, S., El-Khamisy, S.F., Caldecott, K.W., 2007. APLF (C2orf13) is a novel human protein involved in the cellular response to chromosomal DNA strand breaks. Mol. Cell Biol. 27, 3793-3803.

Imamura, O., Fujita, K., Itoh, C., Takeda, S., Furuichi, Y., Matsumoto, T., 2002. Werner and Bloom helicases are involved in DNA repair in a complementary fashion. Oncogene 21, 954-963.

Jette, N., Lees-Miller, S.P., 2015. The DNA-dependent protein kinase: a multifunctional protein kinase with roles in DNA double strand break repair and mitosis. Prog. Biophys. Mol. Biol. 117, 194-205.

Junop, M.S., Modesti, M., Guarne, A., Ghirlando, R., Gellert, M., Yang, W. 2000. Crystal structure of the Xrcc4 DNA repair protein and implications for end joining. EMBO J. 19, 5962-5970.

Kanno, S., Kuzuoka, H., Sasao, S., Hong, Z., Lan, L., Nakajima, S., Yasui, A., 2007. A novel human AP endonuclease with conserved zinc-finger-like motifs involved in DNA strand break responses. EMBO J. 26, 2094-2103.

Karmakar, P., Snowden, C.M., Ramsden, D.A., Bohr, V.A., 2002. Ku heterodimer binds to both ends of the Werner protein and functional interaction occurs at the Werner N-terminus. Nucleic Acids Res. 30, 3583-3591.

Kienker, L.J., Shin, E.K., Meek, K., 2000. Both V(D)J recombination and radioresistance require DNA-PK kinase activity, though minimal levels suffice for V(D)J recombination. Nucleic Acids Res. 28, 2752-2761.

Kumar, V., Alt, F.W., Frock, R.L., 2016. PAXX and XLF DNA repair factors are functionally redundant in joining DNA breaks in a G1-arrested progenitor B-cell line. Proc. Natl. Acad. Sci. U. S. A. 113, 10619-10624.

Kurimasa, A., Kumano, S., Boubnov, N.V., Story, M.D., Tung, C.S., Peterson, S.R., Chen, D.J., 1999. Requirement for the kinase activity of human DNA-dependent protein kinase catalytic subunit in DNA strand break rejoining. Mol. Cell Biol. 19, 3877-3884.

Lachapelle, S., Gagne, J.P., Garand, C., Desbiens, M., Coulombe, Y., Bohr, V.A., Hendzel, M.J., Masson, J.Y., Poirier, G.G., Lebel, M., 2011. Proteome-wide identification of WRN-interacting proteins in untreated and nuclease-treated samples. J. Proteome Res. 10, 1216-1227.

Lamaa, A., Le Bras, M., Skuli, N., Britton, S., Frit, P., Calsou, P., Prats, H., Cammas, A. Millevoi, S., 2016. A novel cytoprotective function for the DNA repair protein Ku in regulating p53 mRNA translation and function. EMBO Rep. 17, 508-518.

Leber, R., Wise, T.W., Mizuta, R., Meek, K., 1998. The XRCC4 gene product is a target for and interacts with the DNA-dependent protein kinase. J. Biol. Chem. 273 $1794-1801$

Lescale, C., Lenden Hasse, H., Blackford, A.N., Balmus, G., Bianchi, J.J., Yu, W., Bacoccina, L., Jarade, A., Clouin, C., Sivapalan, R., Reina-San-Martin, B. Jackson, S.P., Deriano, L., 2016. Specific roles of XRCC4 paralogs PAXX and XLF during V(D)J recombination. Cell Rep. 16, 2967-2979.

Leung, C.C., Glover, J.N., 2011. BRCT domains: easy as one, two, three. Cell Cycle 10 2461-2470.

Li, B., Comai, L., 2000. Functional interaction between Ku and the werner syndrome protein in DNA end processing. J. Biol. Chem. 275, 28349-28352.

Li, B., Comai, L., 2001. Requirements for the nucleolytic processing of DNA ends by the Werner syndrome protein-Ku70/80 complex. J. Biol. Chem. 276, 9896-9902.

Li, G., Alt, F.W., Cheng, H.L., Brush, J.W., Goff, P.H., Murphy, M.M., Franco, S., Zhang, Y., Zha, S., 2008. Lymphocyte-specific compensation for XLF/cernunnos endjoining functions in V(D)J recombination. Mol. Cell 31, 631-640.

Li, G., Nelsen, C., Hendrickson, E.A., 2002. Ku86 is essential in human somatic cells. Proc. Natl. Acad. Sci. U. S. A. 99, 832-837.

Li, Y., Chirgadze, D.Y., Bolanos-Garcia, V.M., Sibanda, B.L., Davies, O.R., Ahnesorg, P. Jackson, S.P., Blundell, T.L., 2007. Crystal structure of human XLF/Cernunnos reveals unexpected differences from XRCC4 with implications for NHEJ. EMBO J. 27, 290-300.

Lieber, M.R., 2010. The mechanism of double-strand DNA break repair by the nonhomologous DNA end-joining pathway. Annu. Rev. Biochem. 79, 181-211.

Liu, X., Shao, Z., Jiang, W., Lee, B.J., Zha, S., 2017. PAXX promotes KU accumulation at DNA breaks and is essential for end-joining in XLF-deficient mice. Nat. Commun. 8, 13816.

Loc'h, J., Delarue, M., 2018. Terminal deoxynucleotidyltransferase: the story of an untemplated DNA polymerase capable of DNA bridging and templated synthesis across strands. Curr. Opin. Struct. Biol. 53, 22-31.

Lu, H., Pannicke, U., Schwarz, K., Lieber, M.R., 2007. Length-dependent binding of human XLF to DNA and stimulation of XRCC4: DNA ligase IV activity. J. Biol. Chem. 282, 11155-11162.

Ma, Y., Lu, H., Tippin, B., Goodman, M.F., Shimazaki, N., Koiwai, O., Hsieh, C.L. Schwarz, K., Lieber, M.R., 2004. A biochemically defined system for mammalian nonhomologous DNA end joining. Mol. Cell 16, 701-713.

Macrae, C.J., McCulloch, R.D., Ylanko, J., Durocher, D., Koch, C.A., 2008. APLF (C2orf13) facilitates nonhomologous end-joining and undergoes ATMdependent hyperphosphorylation following ionizing radiation. DNA Repair 7 , $292-302$.

Mahajan, K.N., Gangi-Peterson, L., Sorscher, D.H., Wang, J., Gathy, K.N., Mahajan, N.P., Reeves, W.H., Mitchell, B.S., 1999. Association of terminal deoxynucleotidyl transferase with Ku. Proc. Natl. Acad. Sci. U. S. A. 96, 13926-13931.

Mahajan, K.N., Nick McElhinny, S.A., Mitchell, B.S., Ramsden, D.A., 2002. Association of DNA polymerase mu ( $\mathrm{pol} \mathrm{mu}$ ) with Ku and ligase IV: role for pol mu in endjoining double-strand break repair. Mol. Cell Biol. 22, 5194-5202.

Mahaney, B.L., Hammel, M., Meek, K., Tainer, J.A., Lees-Miller, S.P., 2013. XRCC4 and XLF form long helical protein filaments suitable for DNA end protection and alignment to facilitate DNA double strand break repair. Biochem. Cell Biol. 91, $31-41$

Malivert, L., Ropars, V., Nunez, M., Devret, P., Miron, S., Faure, G., Guerois, R., Mornon, J.P., Revy, P., Charbonnier, J.B., Callebaut, I., de Villartay, J.P., 2010. Delineation of the XRCC4 interacting region in the globular head domain of cernunnos/XLF. J. Biol. Chem. 285, 26475-26483.

Mari, P.O., Florea, B.I., Persengiev, S.P., Verkaik, N.S., Bruggenwirth, H.T., Modesti, M., Giglia-Mari, G., Bezstarosti, K., Demmers, J.A., Luider, T.M., Houtsmuller, A.B., van Gent, D.C., 2006. Dynamic assembly of end-joining complexes requires interaction between Ku70/80 and XRCC4. Proc. Natl. Acad. Sci. U. S. A. 103, 18597-18602.

Marmignon, A., Bischerour, J., Silve, A., Fojcik, C., Dubois, E., Arnaiz, O., Kapusta, A., Malinsky, S., Betermier, M., 2014. Ku-mediated coupling of DNA cleavage and repair during programmed genome rearrangements in the ciliate Paramecium tetraurelia. PLoS Genet. 10, e1004552.

McGovern, S., Baconnais, S., Roblin, P., Nicolas, P., Drevet, P., Simonson, H., Pietrement, O., Charbonnier, J.B., Le Cam, E., Noirot, P., Lecointe, F., 2016. Cterminal region of bacterial Ku controls DNA bridging. DNA threading and recruitment of DNA ligase D for double strand breaks repair. Nucleic Acids Res. 44, 4785-4806.

Meek, K., Douglas, P., Cui, X., Ding, Q., Lees-Miller, S.P., 2007. Trans autophosphorylation at DNA-PK's two major autophosphorylation site clusters facilitates end processing but not end joining. Mol. Cell Biol. 27, 3881-3890.

Mehrotra, P.V., Ahel, D., Ryan, D.P., Weston, R., Wiechens, N., Kraehenbuehl, R., Owen-Hughes, T., Ahel, I., 2011. DNA repair factor APLF is a histone chaperone. Mol. Cell 41, 46-55.

Menon, V., Povirk, L.F., 2017. XLF/Cernunnos: an important but puzzling participant in the nonhomologous end joining DNA repair pathway. DNA Repair 58, 29-37.

Mimori, T. Hardin, J.A., 1986. Mechanism of interaction between Ku protein and DNA. J. Biol. Chem. 261, 10375-10379.

Mladenov, E., Magin, S., Soni, A., Iliakis, G., 2016. DNA double-strand-break repair in higher Eukaryotes and its role in genomic instability and cancer: cell cycle and proliferation-dependent regulation. Semin. Canc. Biol. 37-38, 51-64.

Modesti, M., Hesse, J.E., Gellert, M., 1999. DNA binding of Xrcc4 protein is associated with $\mathrm{V}(\mathrm{D}) \mathrm{J}$ recombination but not with stimulation of DNA ligase IV activity. EMBO J. 18, 2008-2018.

Mueller, G.A., Moon, A.F., Derose, E.F., Havener, J.M., Ramsden, D.A., Pedersen, L.C., London, R.E., 2008. A comparison of BRCT domains involved in nonhomologous end-joining: introducing the solution structure of the BRCT domain of polymerase lambda. DNA Repair 7, 1340-1351.

Nemoz, C., Ropars, V., Frit, P., Gontier, A., Drevet, P., Yu, J., Guerois, R., Pitois, A., Comte, A., Delteil, C., Barboule, N., Legrand, P., Baconnais, S., Yin, Y., Tadi, S., Barbet-Massin, E., Berger, I., Le Cam, E., Modesti, M., Rothenberg, E., Calsou, P., Charbonnier, J.B., 2018. XLF and APLF bind Ku80 at two remote sites to ensure DNA repair by non-homologous end joining. Nat. Struct. Mol. Biol. 25, 971-980.

Nick McElhinny, S.A., Havener, J.M., Garcia-Diaz, M., Juarez, R., Bebenek, K., Kee, B.L., Blanco, L., Kunkel, T.A., Ramsden, D.A., 2005. A gradient of template dependence defines distinct biological roles for family $\mathrm{X}$ polymerases in nonhomologous end joining. Mol. Cell 19, 357-366.

Ochi, T., Blackford, A.N., Coates, J., Jhujh, S., Mehmood, S., Tamura, N., Travers, J., Wu, Q., Draviam, V.M., Robinson, C.V., Blundell, T.L., Jackson, S.P., 2015. DNA repair. PAXX, a paralog of XRCC4 and XLF, interacts with Ku to promote DNA double-strand break repair. Science 347, 185-188.

Ochi, T., Gu, X., Blundell, T.L., 2013. Structure of the catalytic region of DNA ligase IV in complex with an artemis fragment sheds light on double-strand break repair. Structure 21, 672-679.

Ochi, T., Wu, Q., Blundell, T.L., 2014. The spatial organization of non-homologous end joining: from bridging to end joining. DNA Repair 17, 98-109.

Oshima, J., Huang, S., Pae, C., Campisi, J., Schiestl, R.H., 2002. Lack of WRN results in extensive deletion at nonhomologous joining ends. Cancer Res. 62, 547-551.

Oshima, J., Sidorova, J.M., Monnat Jr., R.J., 2017. Werner syndrome: clinical features, pathogenesis and potential therapeutic interventions. Ageing Res. Rev. 33, 105-114.

Paillard, S., Strauss, F., 1991. Analysis of the mechanism of interaction of simian Ku protein with DNA. Nucleic Acids Res. 19, 5619-5624.

Pang, D., Yoo, S., Dynan, W.S., Jung, M., Dritschilo, A., 1997. Ku proteins join DNA 
fragments as shown by atomic force microscopy. Cancer Res. 57, 1412-1415.

Pannunzio, N.R., Watanabe, G., Lieber, M.R., 2017. Nonhomologous DNA end joining for repair of DNA double-strand breaks. J. Biol. Chem. 293, 10512-10523.

Pasero, P., Vindigni, A., 2017. Nucleases acting at stalled forks: how to reboot the replication program with a few shortcuts. Annu. Rev. Genet. 51, 477-499.

Pawelczak, K.S., Andrews, B.J., Turchi, J.J., 2005. Differential activation of DNA-PK based on DNA strand orientation and sequence bias. Nucleic Acids Res. 33, $152-161$.

Perry, J.J., Yannone, S.M., Holden, L.G., Hitomi, C., Asaithamby, A., Han, S. Cooper, P.K., Chen, D.J., Tainer, J.A., 2006. WRN exonuclease structure and molecular mechanism imply an editing role in DNA end processing. Nat. Struct. Mol. Biol. 13, 414-422.

Pitcher, R.S., Brissett, N.C., Doherty, A.J., 2007. Nonhomologous end-joining in bacteria: a microbial perspective. Annu. Rev. Microbiol. 61, 259-282.

Pryor, J.M., Conlin, M.P., Carvajal-Garcia, J., Luedeman, M.E., Luthman, A.J., Small, G.W., Ramsden, D.A., 2018. Ribonucleotide incorporation enables repair of chromosome breaks by nonhomologous end joining. Science 361, 1126-1129.

Radhakrishnan, S.K., Lees-Miller, S.P., 2017. DNA requirements for interaction of the C-terminal region of Ku80 with the DNA-dependent protein kinase catalytic subunit (DNA-PKcs). DNA Repair 57, 17-28.

Ramsden, D., 2010. Polymerases in Nonhomologous end joining: building a bridge over broken chromosomes. Antioxidants Redox Signal. 14, 2509-2519.

Ramsden, D.A., Asagoshi, K., 2012. DNA polymerases in nonhomologous end joining: are there any benefits to standing out from the crowd? Environ. Mol. Mutagen. 53, 741-751.

Raval, P., Kriatchko, A.N., Kumar, S., Swanson, P.C., 2008. Evidence for Ku70/Ku80 association with full-length RAG1. Nucleic Acids Res. 36, 2060-2072.

Reid, D.A., Keegan, S., Leo-Macias, A., Watanabe, G., Strande, N.T., Chang, H.H., Oksuz, B.A., Fenyo, D., Lieber, M.R., Ramsden, D.A., Rothenberg, E., 2015. Organization and dynamics of the nonhomologous end-joining machinery during DNA double-strand break repair. Proc. Natl. Acad. Sci. U. S. A. 112, E2575-E2584.

Riballo, E., Woodbine, L., Stiff, T., Walker, S.A., Goodarzi, A.A., Jeggo, P.A., 2008. XLFCernunnos promotes DNA ligase IV-XRCC4 re-adenylation following ligation. Nucleic Acids Res. 37, 482-492.

Rivera-Calzada, A., Spagnolo, L., Pearl, L.H., Llorca, O., 2006. Structural model of fulllength human Ku70-Ku80 heterodimer and its recognition of DNA and DNAPKcs. EMBO Rep. 8, 56-62.

Roberts, S.A., Ramsden, D.A., 2007. Loading of the nonhomologous end joining factor, KU, on protein-occluded DNA ends. J. Biol. Chem. 282, 10605-10613.

Ropars, V., Drevet, P., Legrand, P., Baconnais, S., Amram, J., Faure, G., Marquez, J.A., Pietrement, O., Guerois, R., Callebaut, I., Le Cam, E., Revy, P., de Villartay, J.P., Charbonnier, J.B., 2011. Structural characterization of filaments formed by human Xrcc4-Cernunnos/XLF complex involved in nonhomologous DNA endjoining. Proc. Natl. Acad. Sci. U. S. A. 108, 12663-12668.

Rossi, M.L., Ghosh, A.K., Bohr, V.A., 2010. Roles of Werner syndrome protein in protection of genome integrity. DNA Repair 9, 331-344.

Roy, S., Andres, S.N., Vergnes, A., Neal, J.A., Xu, Y., Yu, Y., Lees-Miller, S.P., Junop, M., Modesti, M., Meek, K., 2012. XRCC4's interaction with XLF is required for coding (but not signal) end joining. Nucleic Acids Res. 40, 1684-1694.

Roy, S., de Melo, A.J., Xu, Y., Tadi, S.K., Negrel, A., Hendrickson, E., Modesti, M., Meek, K., 2015. XRCC4/XLF interaction is variably required for DNA repair, and is not required for Ligase IV stimulation. Mol. Cell Biol. 35, 3017-3028.

Rulten, S.L., Cortes-Ledesma, F., Guo, L., Iles, N.J., Caldecott, K.W., 2008. APLF (C2orf13) is a novel component of poly(ADP-ribose) signaling in mammalian cells. Mol. Cell Biol. 28, 4620-4628.

Rulten, S.L., Grundy, G.J., 2017. Non-homologous end joining: common interaction sites and exchange of multiple factors in the DNA repair process. Bioessays 39. https://doi.org/10.1002/bies.201600209.

Schipler, A., Iliakis, G., 2013. DNA double-strand-break complexity levels and their possible contributions to the probability for error-prone processing and repair pathway choice. Nucleic Acids Res. 41, 7589-7605.

Shamanna, R.A., Croteau, D.L., Lee, J.H., Bohr, V.A., 2017. Recent Advances in Understanding Werner Syndrome. F1000Res., vol. 6, p. 1779.

Shamanna, R.A., Lu, H., de Freitas, J.K., Tian, J., Croteau, D.L., Bohr, V.A., 2016. WRN regulates pathway choice between classical and alternative non-homologous end joining. Nat. Commun. 7, 13785 .

Sharif, H., Li, Y., Dong, Y., Dong, L., Wang, W.L., Mao, Y., Wu, H., 2017. Cryo-EM structure of the DNA-PK holoenzyme. Proc. Natl. Acad. Sci. U. S. A. 114, 7367-7372.

Shirodkar, P., Fenton, A.L., Meng, L., Koch, C.A., 2013. Identification and functional characterization of a Ku-binding motif in Aprataxin Polynucleotide kinase/ phosphatase-Like Factor (APLF). J. Biol. Chem. 288, 19604-19613.

Sibanda, B.L., Chirgadze, D.Y., Ascher, D.B., Blundell, T.L., 2017. DNA-PKcs structure suggests an allosteric mechanism modulating DNA double-strand break repair. Science 355, 520-524.

Sibanda, B.L., Chirgadze, D.Y., Blundell, T.L., 2010. Crystal structure of DNA-PKcs reveals a large open-ring cradle comprised of HEAT repeats. Nature 463, $118-121$.

Sibanda, B.L., Critchlow, S.E., Begun, J., Pei, X.Y., Jackson, S.P., Blundell, T.L., Pellegrini, L., 2001. Crystal structure of an Xrcc4-DNA ligase IV complex. Nat. Struct. Biol. 8, 1015-1019.

Singleton, B.K., Torres-Arzayus, M.I., Rottinghaus, S.T., Taccioli, G.E., Jeggo, P.A., 1999. The $C$ terminus of Ku80 activates the DNA-dependent protein kinase catalytic subunit. Mol. Cell Biol. 19, 3267-3277.

Slavoff, S.A., Heo, J., Budnik, B.A., Hanakahi, L.A., Saghatelian, A., 2014. A human short open reading frame (sORF)-encoded polypeptide that stimulates DNA end joining. J. Biol. Chem. 289, 10950-10957.

Spagnolo, L., Rivera-Calzada, A., Pearl, L.H., Llorca, O., 2006. Three-dimensional structure of the human DNA-PKcs/Ku70/Ku80 complex assembled on DNA and its implications for DNA DSB repair. Mol. Cell 22, 511-519.

Suwa, A., Hirakata, M., Takeda, Y., Jesch, S.A., Mimori, T., Hardin, J.A., 1994. DNAdependent protein kinase (Ku protein-p350 complex) assembles on doublestranded DNA. Proc. Natl. Acad. Sci. U. S. A. 91, 6904-6908.

Tadi, S.K., Tellier-Lebegue, C., Nemoz, C., Drevet, P., Audebert, S., Roy, S., Meek, K. Charbonnier, J.B., Modesti, M., 2016. PAXX is an accessory c-NHEJ factor that associates with Ku70 and has overlapping functions with XLF. Cell Rep. 17 $541-555$.

Tsai, C.J., Kim, S.A., Chu, G., 2007. Cernunnos/XLF promotes the ligation of mismatched and noncohesive DNA ends. Proc. Natl. Acad. Sci. U. S. A. 104 $7851-7856$.

Turchi, J.J., Henkels, K., 1996. Human Ku autoantigen binds cisplatin-damaged DNA but fails to stimulate human DNA-activated protein kinase. J. Biol. Chem. 271, $13861-13867$.

Uematsu, N., Weterings, E., Yano, K.I., Morotomi-Yano, K., Jakob, B., TaucherScholz, G., Mari, P.O. van Gent, D.C., Chen, B.P., Chen, D.J. 2007. Autophosphorylation of DNA-PKCS regulates its dynamics at DNA double-strand breaks. J. Cell Biol. 177, 219-229.

Vera, G., Rivera-Munoz, P., Abramowski, V., Malivert, L., Lim, A., Bole-Feysot, C., Martin, C., Florkin, B., Latour, S., Revy, P., de Villartay, J.P., 2012. Cernunnos deficiency reduces thymocyte lifespan and alters the T cell repertoire in mice and humans. Mol. Cell Biol. 33, 701-711.

Walker, J.R., Corpina, R.A., Goldberg, J., 2001. Structure of the Ku heterodimer bound to DNA and its implications for double-strand break repair. Nature 412, 607-614.

Wang, J.L., Duboc, C., Wu, Q., Ochi, T., Liang, S., Tsutakawa, S.E., Lees-Miller, S.P., Nadal, M., Tainer, J.A., Blundell, T.L., Strick, T.R., 2018. Dissection of DNA doublestrand-break repair using novel single-molecule forceps. Nat. Struct. Mol. Biol. $25,482-487$.

Waters, C.A., Strande, N.T., Wyatt, D.W., Pryor, J.M., Ramsden, D.A. 2014, Nonhomologous end joining: a good solution for bad ends. DNA Repair 17, 39-51.

Weterings, E., Verkaik, N.S., Keijzers, G., Florea, B.I., Wang, S.Y., Ortega, L.G. Uematsu, N., Chen, D.J., van Gent, D.C., 2009. The Ku80 carboxy terminus stimulates joining and artemis-mediated processing of DNA ends. Mol. Cell Biol. 29, 1134-1142.

Williams, D.R., Lee, K.J., Shi, J., Chen, D.J., Stewart, P.L., 2008. Cryo-EM structure of the DNA-dependent protein kinase catalytic subunit at subnanometer resolution reveals alpha helices and insight into DNA binding. Structure 16, 468-477.

Williams, G.J., Hammel, M., Radhakrishnan, S.K., Ramsden, D., Lees-Miller, S.P. Tainer, J.A., 2014. Structural insights into NHEJ: building up an integrated picture of the dynamic DSB repair super complex, one component and interaction at a time. DNA Repair 17, 110-120.

Woodbine, L., Gennery, A.R., Jeggo, P.A., 2014. The clinical impact of deficiency in DNA non-homologous end-joining. DNA Repair 16, 84-96.

Woods, D.S., Sears, C.R., Turchi, J.J., 2015. Recognition of DNA termini by the Cterminal region of the Ku80 and the DNA-dependent protein kinase catalytic subunit. PLoS One 10, e0127321.

Wu, P.Y., Frit, P., Malivert, L., Revy, P., Biard, D., Salles, B., Calsou, P., 2007. Interplay between cernunnos-XLF and NHEJ proteins at DNA ends in the cell. J. Biol. Chem. 282, 31937-31943.

Wu, P.Y., Frit, P., Meesala, S., Dauvillier, S., Modesti, M., Andres, S.N., Huang, Y., Sekiguchi, J., Calsou, P., Salles, B., Junop, M.S., 2009. Structural and functional interaction between the human DNA repair proteins DNA Ligase IV and XRCC4. Mol. Cell Biol. 29, 3163-3172.

Wu, Q., Ochi, T., Matak-Vinkovic, D., Robinson, C.V., Chirgadze, D.Y., Blundell, T.L. 2011. Non-homologous end-joining partners in a helical dance: structural studies of XLF-XRCC4 interactions. Biochem. Soc. Trans. 39, 1387-1392.

Xing, M., Yang, M., Huo, W., Feng, F., Wei, L., Jiang, W., Ning, S., Yan, Z., Li, W., Wang, Q., Hou, M., Dong, C., Guo, R., Gao, G., Ji, J., Zha, S., Lan, L., Liang, H., Xu, D. 2015. Interactome analysis identifies a new paralogue of XRCC4 in nonhomologous end joining DNA repair pathway. Nat. Commun. 6, 6233.

Xue, Y., Ratcliff, G.C., Wang, H., Davis-Searles, P.R., Gray, M.D., Erie, D.A. Redinbo, M.R., 2002. A minimal exonuclease domain of WRN forms a hexamer on DNA and possesses both 3'- 5' exonuclease and 5'-protruding strand endonuclease activities. Biochemistry 41, 2901-2912.

Yannone, S.M., Roy, S., Chan, D.W., Murphy, M.B., Huang, S., Campisi, J., Chen, D.J., 2001. Werner syndrome protein is regulated and phosphorylated by DNAdependent protein kinase. J. Biol. Chem. 276, 38242-38248.

Yano, K.I., Chen, D.J., 2008. Live cell imaging of XLF and XRCC4 reveals a novel view of protein assembly in the non-homologous end-joining pathway. Cell Cycle 7, $1321-1325$.

Yano, K.I., Morotomi-Yano, K., Lee, K.J., Chen, D.J., 2011. Functional significance of the interaction with Ku in DNA double-strand break recognition of XLF. FEBS Lett. $585,841-846$.

Yano, K.I., Morotomi-Yano, K., Wang, S.Y., Uematsu, N., Lee, K.J., Asaithamby, A. Weterings, E., Chen, D.J., 2007. Ku recruits XLF to DNA double-strand breaks. EMBO Rep. 9, 91-96.

Yin, X., Liu, M., Tian, Y., Wang, J., Xu, Y., 2017. Cryo-EM structure of human DNA-PK holoenzyme. Cell Res. 27, 1341-1350.

Yokote, K., Chanprasert, S., Lee, L., Eirich, K., Takemoto, M., Watanabe, A., Koizumi, N., Lessel, D., Mori, T., Hisama, F.M., Ladd, P.D., Angle, B., Baris, H. 
Cefle, K., Palanduz, S., Ozturk, S., Chateau, A., Deguchi, K., Easwar, T.K., Federico, A., Fox, A., Grebe, T.A., Hay, B., Nampoothiri, S., Seiter, K., Streeten, E., Pina-Aguilar, R.E., Poke, G., Poot, M., Posmyk, R., Martin, G.M., Kubisch, C. Schindler, D., Oshima, J., 2017. WRN mutation update: mutation spectrum, patient registries, and translational prospects. Hum. Mutat. 38, 7-15.

Yoo, S., Kimzey, A., Dynan, W.S., 1999. Photocross-linking of an oriented DNA repair complex. Ku bound at a single DNA end. J. Biol. Chem. 274, 20034-20039.
Zhang, Q., Karnak, D., Tan, M., Lawrence, T.S., Morgan, M.A., Sun, Y., 2016. FBXW7 facilitates nonhomologous end-joining via K63-linked polyubiquitylation of XRCC4. Mol. Cell 61, 419-433.

Zhao, Y., Thomas, H.D., Batey, M.A., Cowell, I.G., Richardson, C.J., Griffin, R.J., Calvert, A.H., Newell, D.R., Smith, G.C., Curtin, N.J., 2006. Preclinical Evaluation of a potent novel DNA-dependent protein kinase inhibitor NU7441. Cancer Res. 66, 5354-5362. 